\title{
Transactions
}

Cite this: Dalton Trans., 2012, 41, 1695

wWW.rsc.org/dalton

PAPER

\section{The role of $\mathrm{Zn}-\mathrm{OR}$ and $\mathrm{Zn}-\mathrm{OH}$ nucleophiles and the influence of para-substituents in the reactions of binuclear phosphatase mimetics $\uparrow$}

\author{
Lena J. Daumann, ${ }^{a}$ Kristian E. Dalle, ${ }^{a}$ Gerhard Schenk, ${ }^{a}$ Ross P. McGeary, ${ }^{a}$ Paul V. Bernhardt, ${ }^{a}$ \\ David L. Ollis ${ }^{b}$ and Lawrence R. Gahan*a
}

Received 23rd June 2011, Accepted 4th October 2011

DOI: $10.1039 / \mathrm{c} 1 \mathrm{dt11187f}$

\begin{abstract}
Analogues of the ligand 2,2'-(2-hydroxy-5-methyl-1,3-phenylene)bis(methylene)bis((pyridin2-ylmethyl)azanediyl)diethanol $\left(\mathrm{CH}_{3} \mathrm{H}_{3} \mathbf{L 1}\right)$ are described. Complexation of these analogues, 2,6-bis(((2-methoxyethyl)(pyridin-2-ylmethyl)amino)methyl)-4-methylphenol $\left(\mathrm{CH}_{3} \mathrm{HL2}\right)$, 4-bromo-2,6-bis(((2-methoxyethyl)(pyridin-2-ylmethyl)amino)methyl)phenol (BrHL2), 2,6-bis(((2-methoxyethyl)(pyridin-2-ylmethyl)amino)methyl)-4-nitrophenol $\left(\mathrm{NO}_{2} \mathrm{HL2}\right)$ and 4-methyl-2,6-bis(((2-phenoxyethyl)(pyridin-2-ylmethyl)amino)methyl)phenol $\left(\mathrm{CH}_{3} \mathrm{HL3}\right)$ with zinc(II) acetate afforded $\left[\mathrm{Zn}_{2}\left(\mathrm{CH}_{3} \mathbf{L 2}\right)\left(\mathrm{CH}_{3} \mathrm{COO}\right)_{2}\right]\left(\mathrm{PF}_{6}\right),\left[\mathrm{Zn}_{2}\left(\mathrm{NO}_{2} \mathbf{L 2}\right)\left(\mathrm{CH}_{3} \mathrm{COO}\right)_{2}\right]\left(\mathrm{PF}_{6}\right)$, $\left[\mathrm{Zn}_{2}(\mathrm{BrL2})\left(\mathrm{CH}_{3} \mathrm{COO}\right)_{2}\right]\left(\mathrm{PF}_{6}\right)$ and $\left[\mathrm{Zn}_{2}\left(\mathrm{CH}_{3} \mathbf{L 3}\right)\left(\mathrm{CH}_{3} \mathrm{COO}\right)_{2}\right]\left(\mathrm{PF}_{6}\right)$, in addition to $\left[\mathrm{Zn}_{4}\left(\mathrm{CH}_{3} \mathbf{L 2}\right)_{2}\left(\mathrm{NO}_{2} \mathrm{C}_{6} \mathrm{H}_{5} \mathrm{OPO}_{3}\right)_{2}\left(\mathrm{H}_{2} \mathrm{O}\right)_{2}\right]\left(\mathrm{PF}_{6}\right)_{2}$ and $\left[\mathrm{Zn}_{4}(\mathrm{BrL2})_{2}\left(\mathrm{PO}_{3} \mathrm{~F}\right)_{2}\left(\mathrm{H}_{2} \mathrm{O}\right)_{2}\right]\left(\mathrm{PF}_{6}\right)_{2}$. The complexes were characterized using ${ }^{1} \mathrm{H}$ and ${ }^{13} \mathrm{C}$ NMR spectroscopy, mass spectrometry, microanalysis, and $\mathrm{X}$-ray crystallography. The complexes contain either a coordinated methyl- (L2 ligands) or phenyl- (L3 ligand) ether, replacing the potentially nucleophilic coordinated alcohol in the previously reported complex $\left[\mathrm{Zn}_{2}\left(\mathrm{CH}_{3} \mathrm{HL1}\right)\left(\mathrm{CH}_{3} \mathrm{COO}\right)\left(\mathrm{H}_{2} \mathrm{O}\right)\right]\left(\mathrm{PF}_{6}\right)$. Functional studies of the zinc complexes with the substrate bis(2,4-dinitrophenyl) phosphate (BDNPP) showed them to be competent catalysts with, for example, $\left[\mathrm{Zn}_{2}\left(\mathrm{CH}_{3} \mathbf{L 2}\right)\right]^{+}, k_{\text {cat }}=5.70 \pm 0.04 \times 10^{-3} \mathrm{~s}^{-1}\left(K_{\mathrm{m}}=20.8 \pm 5.0 \mathrm{mM}\right)$ and $\left[\mathrm{Zn}_{2}\left(\mathrm{CH}_{3} \mathbf{L 3}\right)\right]^{+}, k_{\text {cat }}=3.60 \pm 0.04 \times$ $10^{-3} \mathrm{~s}^{-1}\left(K_{\mathrm{m}}=18.9 \pm 3.5 \mathrm{mM}\right)$. Catalytically relevant $\mathrm{p} K_{\mathrm{a}} \mathrm{s}$ of 6.7 and 7.7 were observed for the zinc(II) complexes of $\mathrm{CH}_{3} \mathbf{L 2}^{-}$and $\mathrm{CH}_{3} \mathbf{L 3}^{-}$, respectively. Electron donating para-substituents enhance the rate of hydrolysis of BDNPP such that $k_{\text {cat }} p-\mathrm{CH}_{3}>p-\mathrm{Br}>p-\mathrm{NO}_{2}$. Use of a solvent mixture containing $\mathrm{H}_{2} \mathrm{O}^{18} / \mathrm{H}_{2} \mathrm{O}^{16}$ in the reaction with BDNPP showed that for $\left[\mathrm{Zn}_{2}\left(\mathrm{CH}_{3} \mathbf{L 2}\right)\left(\mathrm{CH}_{3} \mathrm{COO}\right)_{2}\right]\left(\mathrm{PF}_{6}\right)$ and $\left[\mathrm{Zn}_{2}\left(\mathrm{NO}_{2} \mathbf{L 2}\right)\left(\mathrm{CH}_{3} \mathrm{COO}\right)_{2}\right]\left(\mathrm{PF}_{6}\right)$, as well as $\left[\mathrm{Zn}_{2}\left(\mathrm{CH}_{3} \mathrm{HL1}\right)\left(\mathrm{CH}_{3} \mathrm{COO}\right)\left(\mathrm{H}_{2} \mathrm{O}\right)\right]\left(\mathrm{PF}_{6}\right)$, the ${ }^{18} \mathrm{O}$ label was incorporated in the product of the hydrolysis suggesting that the nucleophile involved in the hydrolysis reaction was a $\mathrm{Zn}-\mathrm{OH}$ moiety. The results are discussed with respect to the potential nucleophilic species (coordinated deprotonated alcohol versus coordinated hydroxide).
\end{abstract}

\section{Introduction}

Organophosphorous compounds (OPs) are amongst the most commonly used pesticides. ${ }^{1}$ They act by inhibiting acetylcholinesterase thus preventing proper functioning of nerve cells. This property has resulted in OPs such as sarin, soman and VX finding application as nerve agents. ${ }^{1-3}$ OP-hydrolyzing enzymes are common ${ }^{2-5}$ and were initially thought to natively contain a single $\mathrm{Zn}$ (II) in the active site, ${ }^{6}$ but more recent analysis by atomic absorption spectroscopy and X-ray anomalous scattering suggested that the active form of these enzymes is binuclear with

${ }^{a}$ School of Chemistry and Molecular Biosciences, The University of Queensland, Brisbane, QLD 4072, Australia.E-mail: gahan@uq.edu.au

${ }^{b}$ Research School of Chemistry, Australian National University, Canberra, ACT 0200, Australia

$\dagger$ CCDC reference numbers 830841-830846. For crystallographic data in CIF or other electronic format see DOI: $10.1039 / \mathrm{cldt11187f}$ combinations such as $\mathrm{Zn}$ (II)/Fe(II) likely. ${ }^{7}$ The enzymes are also catalytically active as $\mathrm{Co}(\mathrm{II}), \mathrm{Cd}(\mathrm{II}), \mathrm{Mn}$ (II) or Ni(II) substituted forms. ${ }^{8,9}$ The active site is typically composed of a nitrogen/oxygen coordination environment for two divalent metal ions coordinated by nitrogen donors located on histidine ligands, oxygen donors typically from an aspartate, and often including a metal ionbridging hydroxide ion. ${ }^{10-14}$

Model complexes capable of reproducing the electronic, structural and reactivity characteristics of OP-hydrolyzing metalloenzyme systems generally exhibit less substrate specificity and are often more robust than the metalloenzymes themselves. ${ }^{15-18}$ The question of the nucleophilic agent in these models, and often with the enzymes themselves, requires examination. In most hydrolytic enzymes a metal-hydroxide is suggested as the nucleophile in the key hydrolysis step, although exogenous alcohol moieties are also implicated..$^{19,20}$ Examples of model systems with either or both a metal-OH and a metal-OR present, which are 
implicated in the mechanism, have been reported ${ }^{21-24}$ Interestingly, a coordinated alcohol is a stronger nucleophile than a coordinated hydroxide ${ }^{21,23-28}$ and there is evidence that the coordinated alcohol is deprotonated at or below the same $\mathrm{pH}$ as a coordinated water molecule, particularly in the case of zinc(II) complexes. ${ }^{22}$

In this work we have explored the role of the coordinated alcohol and a coordinated water molecule using zinc(II) complexes of the previously described ligand 2,2'-(2-hydroxy-5-methyl1,3-phenylene)bis(methylene)bis((pyridin-2-ylmethyl)azanediyl)diethanol $\left(\mathrm{CH}_{3} \mathrm{H}_{3} \mathbf{L 1}\right){ }^{24}$ and analogues of this ligand, 2,6-bis(((2-methoxyethyl)(pyridin-2-ylmethyl)amino)methyl)-4-methylphenol $\left(\mathrm{CH}_{3} \mathrm{HL2}\right)$ and 4-methyl-2,6-bis(((2-phenoxyethyl)(pyridin-2-ylmethyl)amino)methyl)phenol $\left(\mathrm{CH}_{3} \mathrm{HL3}\right)$. In addition, the chemistry of the substituted zinc(II) complexes of 2,6-bis(((2-methoxyethyl)(pyridin-2-ylmethyl)amino)methyl)4-nitrophenol $\left(\mathrm{NO}_{2} \mathrm{HL2}\right)$ and 4-bromo-2,6-bis(((2-methoxyethyl)(pyridin-2-ylmethyl)amino)methyl)phenol (BrHL2) has been studied (Chart 1). The catalytic potential of these complexes has been explored using the phosphodiester substrate bis(2,4dinitrophenyl) phosphate (BDNPP).

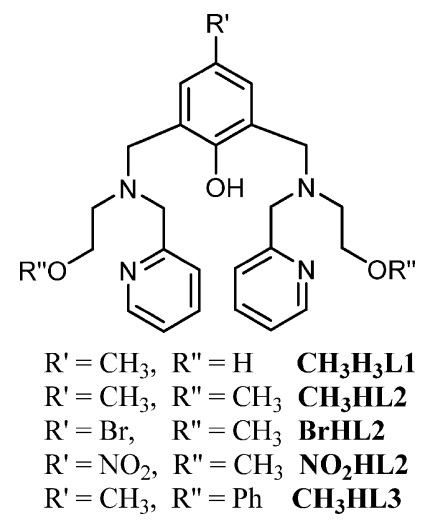

Chart 1 Ligands discussed in this work.

\section{Results and discussion}

\section{Syntheses and nomenclature of ligands and complexes}

The previously reported ligand 2,2'-(2-hydroxy-5-methyl-1,3-phenylene)bis(methylene)bis((pyridin-2-ylmethyl)azanediyl)diethanol $\left(\mathrm{CH}_{3} \mathrm{H}_{3} \mathbf{L 1}\right),{ }^{24}$ in addition to 2,6-bis $(((2-m e t h o x y e t h y l)-$ (pyridin-2-ylmethyl)amino)methyl)-4-methylphenol $\quad\left(\mathrm{CH}_{3} \mathrm{HL2}\right)$ and 4-methyl-2,6-bis(((2-phenoxyethyl)(pyridin-2-ylmethyl)amino)methyl)phenol $\left(\mathrm{CH}_{3} \mathrm{HL3}\right)$ have been synthesized through a substitution reaction between 2,6-bis(chloromethyl)-4methylphenol and 2-methoxy- $N$-(pyridin-2-ylmethyl)ethanamine and 2-phenoxy- $N$-(pyridin-2-ylmethyl)ethanamine, respectively. The 2-pyridylmethyl-2-hydroxyethylamine derivatives were prepared by condensation of 2-methoxyethanolamine and 2-phenoxyethanolamine with pyridine-2-carboxaldehyde at room temperature, followed by reduction with sodium borohydride. These ligands offer a direct comparison of methyl and phenyl ether donors with the alkoxide donor in the complex $\left[\mathrm{Zn}_{2}\left(\mathrm{CH}_{3} \mathrm{HL1}\right)\left(\mathrm{CH}_{3} \mathrm{COO}\right)\left(\mathrm{H}_{2} \mathrm{O}\right)\right]\left(\mathrm{PF}_{6}\right){ }^{24}$ The ligands, 4-bromo-2,6-bis(((2-methoxyethyl)(pyridin2-ylmethyl)amino)methyl)phenol (BrHL2) and 2,6-bis(((2- methoxyethyl)(pyridin-2-ylmethyl)amino)methyl)-4-nitrophenol $\left(\mathrm{NO}_{2} \mathrm{HL2}\right)$ are analogues of $\mathrm{CH}_{3} \mathrm{HL2}$ with bromo- and nitrosubstituents in the para-positions of the phenoxide, respectively. The syntheses are described in Scheme 1. The di-zinc(II) complexes of these ligands were prepared after reaction with zinc acetate and X-ray quality crystals were produced either on standing or by recrystallization.

The nomenclature employed for the ligands denotes the number of labile protons upon complexation and the substituent on the para-position of the phenoxide. Hence $\mathrm{NO}_{2} \mathrm{HL} 2$ and BrHL2 are derivatives of the methyl ether parent $\left(\mathrm{CH}_{3} \mathrm{HL2}\right)$ and have one potential site for deprotonation, the phenolic $\mathrm{OH}$; complexation as $\mathrm{NO}_{2} \mathbf{L 2}^{-}$and $\mathrm{BrL2}^{-}$implies a single deprotonation. Thus, the previously reported complex with $\mathrm{CH}_{3} \mathrm{H}_{3} \mathbf{L 1}$, with a methyl substituent in the para- position and with potential sites for deprotonation being the phenol and the two pendant alcohol donors, was characterized as $\left[\mathrm{Zn}_{2}\left(\mathrm{CH}_{3} \mathrm{HL1}\right)\left(\mathrm{CH}_{3} \mathrm{COO}\right)\left(\mathrm{H}_{2} \mathrm{O}\right)\right]\left(\mathrm{PF}_{6}\right)$ indicating complexation as $\mathrm{CH}_{3} \mathrm{HL1}^{2-}$ with deprotonation at the phenol and one alcohol. ${ }^{24}$ The ligand $\mathrm{CH}_{3} \mathrm{HL3}$ has a methyl substituent, one site for deprotonation and phenyl-ether pendants. Previous studies with the ligand $\mathrm{CH}_{3} \mathrm{H}_{3} \mathbf{L} \mathbf{1}$ have employed different nomenclature $(\mathrm{L}) ;{ }^{24}$ the current nomenclature attempts to make more ready comparison between the various ligands reported herein. Ligands employed in this work are shown in Chart 1.

\section{Solid state structures}

The homologous series of binuclear complexes $\left[\mathrm{Zn}_{2}\left(\mathrm{CH}_{3} \mathbf{L 2}\right)\right.$ $\left.\left(\mathrm{CH}_{3} \mathrm{COO}\right)_{2}\right]\left(\mathrm{PF}_{6}\right), \quad\left[\mathrm{Zn}_{2}\left(\mathrm{CH}_{3} \mathbf{L} 3\right)\left(\mathrm{CH}_{3} \mathrm{COO}\right)_{2}\right]\left(\mathrm{PF}_{6}\right) \cdot \mathrm{CH}_{3} \mathrm{OH}$, $\left[\mathrm{Zn}_{2}(\mathrm{BrL2})\left(\mathrm{CH}_{3} \mathrm{COO}\right)_{2}\right]\left(\mathrm{PF}_{6}\right)$ and $\left[\mathrm{Zn}_{2}\left(\mathrm{NO}_{2} \mathbf{L 2}\right)\left(\mathrm{CH}_{3} \mathrm{COO}\right)_{2}\right]-$ $\left(\mathrm{PF}_{6}\right)$ were isolated and characterized structurally. In all cases the structures comprised the ligand monoanion, two zinc(II) ions and two bridging acetates with a hexafluorophosphate anion. The four complexes adopt the anti-configuration with respect to the plane of the phenoxide ring, ${ }^{29}$ as does the complex $\left[\mathrm{Zn}_{2}\left(\mathrm{CH}_{3} \mathrm{HL1}\right)\left(\mathrm{CH}_{3} \mathrm{COO}\right)\left(\mathrm{H}_{2} \mathrm{O}\right)\right]\left(\mathrm{PF}_{6}\right){ }^{24}$ For the complex with $\mathrm{CH}_{3} \mathbf{L} \mathbf{3}$ a methanol solvate was present. In some instances the $\mathrm{PF}_{6}{ }^{-}$was resolved into two disordered octahedral anions sharing the same central atom. Selected crystallographic data are shown in Table 1 and selected bond lengths and angles are displayed in Table 2. ORTEP plots of the complex cations are shown in Fig. $1 .^{30}$ In all cases the complexes have the phenolate bridging the two zinc(II) centers which are six-coordinate. For $\left[\mathrm{Zn}_{2}\left(\mathrm{CH}_{3} \mathbf{L 2}\right)\left(\mathrm{CH}_{3} \mathrm{COO}\right)_{2}\right]\left(\mathrm{PF}_{6}\right)$, $\left[\mathrm{Zn}_{2}(\mathrm{BrL2})\left(\mathrm{CH}_{3} \mathrm{COO}\right)_{2}\right]\left(\mathrm{PF}_{6}\right), \quad\left[\mathrm{Zn}_{2}\left(\mathrm{NO}_{2} \mathbf{L 2}\right)\left(\mathrm{CH}_{3} \mathrm{COO}\right)_{2}\right]\left(\mathrm{PF}_{6}\right)$ and $\left[\mathrm{Zn}_{2}\left(\mathrm{CH}_{3} \mathbf{L 3}\right)\left(\mathrm{CH}_{3} \mathrm{COO}\right)_{2}\right]\left(\mathrm{PF}_{6}\right)$ the coordination environment of both metal ions is composed of the tertiary amine $(\mathrm{Zn}(1)-\mathrm{N}(3): 2.184(3), 2.196(4), 2.193(3), 2.200(4) \AA$ $\mathrm{Zn}(2)-\mathrm{N}(1): 2.188(3), 2.206(4), 2.197(3), 2.187(4) \AA)$, the pyridine nitrogen $(\mathrm{Zn}(1)-\mathrm{N}(4)$ : 2.123(3), 2.114(4), 2.134(4), 2.108(4) $\AA$; $\mathrm{Zn}(2)-\mathrm{N}(2): 2.148(3), 2.127(4), 2.129(4), 2.123(4) \AA)$, and the ether oxygens ( $\mathrm{Zn}(1)-\mathrm{O}(5): 2.397(3), 2.433(4), 2.380(4), 2.807 \AA$; $\mathrm{Zn}(2)-\mathrm{O}(4): 2.467(3), 2.368(4), 2.323(3), 2.564 \AA)$, respectively, in addition to the bridging acetates. The six-coordinate geometry is completed by the bridging oxygen from the phenolate $(\mathrm{Zn}(1)$ $\mathrm{O}(1): 2.006(2), 2.007(3), 2.043(3), 2.003(3) \AA ; \quad \mathrm{Zn}(2)-\mathrm{O}(1)$ : 2.024(3), 2.020(3), 2.041(3), 2.024(3) ̊̊) with $\mathrm{Zn}(1)-\mathrm{O}(1)-\mathrm{Zn}(2)$ $109.70(11)^{\circ}, 110.21(14)^{\circ}, 109.73(13)^{\circ}$ and $107.49(16)^{\circ}$ and $\mathrm{Zn}(1)$ $\mathrm{Zn}$ (2) distances of 3.296, 3.304, 3.341 and $3.247 \AA$, respectively. 


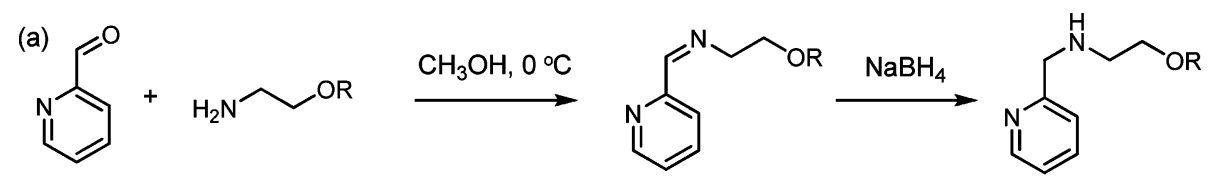<smiles>[R]CCN(CCc1cc(C)cc(CN(CCO[R6])Cc2ccccn2)c1O)Cc1ccccn1</smiles><smiles>CO[C@H](OCc1cc([N+](=O)[O-])cc2c1OCOC2)c1cc(Br)cc([N+](=O)[O-])c1</smiles><smiles>COCCN(Cc1ccccn1)Cc1cc([N+](=O)[O-])cc(CN(CCOC)Cc2ccccn2)c1O</smiles>

(e)<smiles>O=C(O)C[C@H](O)c1cc(Br)ccc1OCc1cc(Br)cc(CO)c1O</smiles>

(f)<smiles>Oc1c(Br)cc(Br)cc1CBr</smiles><smiles>COCCN(Cc1ccccn1)Cc1cc(Br)cc(CN(CCOC)Cc2ccccn2)c1O</smiles>

Scheme 1 Synthesis of (a) and (b) 2,6-bis(((2-methoxyethyl)(pyridin-2-ylmethyl)amino)methyl)-4-methylphenol $\left(\mathrm{CH}_{3} \mathrm{HL2}_{2}\right.$ and 4-methyl-2,6-bis(((2phenoxyethyl)(pyridin-2-ylmethyl)amino)methyl)phenol $\left(\mathrm{CH}_{3} \mathrm{HL3}\right)$; (c) bis(bromomethyl)-4-nitrophenol; (d) 2,6-bis(((2-methoxyethyl)(pyridin-2-ylmethyl)amino)methyl)-4-nitrophenol ( $\left.\mathrm{NO}_{2} \mathrm{HL2}\right)$; (e) 4-bromo-2,6-bis(bromomethyl)phenol; and, (f) 4-bromo-2,6-bis(((2-methoxyethyl)(pyridin-2-ylmethyl)amino)methyl)phenol (BrHL2).

The $\mathrm{Zn}-\mathrm{O}$ (phenolate) and $\mathrm{Zn}-\mathrm{N}$ distances appear typical of those reported in this type of complex. The $\mathrm{Zn}-\mathrm{O}$ (ether) distances are at the long end of the range seen previously for the $\mathrm{Zn}$ (II) complexes of 2,6-bis(bis(2-methoxyethyl)aminomethyl)-4-methylphenol (Hbomp; $\left[\mathrm{Zn}_{2}\right.$ (bomp) $\left.\left(\mathrm{CH}_{3} \mathrm{COO}\right)_{2}\right] \mathrm{BPh}_{4} ; 2.214(5), 2.197(3)$, 2.362(4), 2.440(3) §), ${ }^{31}$ and 1,2-dimethoxyethane (glyme) $\left(\left[\mathrm{Zn}_{2} \mathrm{Cl}_{2}\right.\right.$ (glyme) $, \quad 2.1286(11), 2.1216(10) \AA ; \quad\left[\mathrm{Zn}_{2} \mathrm{I}_{2}\right.$ (glyme) $2.067(7) \AA)^{32,33}$ and are significantly longer than those observed for the deprotonated alkoxide $\left(\mathrm{Zn}-\mathrm{O}^{-}\right)$distances (1.906(3) $\AA$ ) and coordinated water $(2.074(3) \AA)$ reported for $\left[\mathrm{Zn}_{2}\left(\mathrm{CH}_{3} \mathrm{HL1}\right)\left(\mathrm{CH}_{3} \mathrm{COO}\right)\left(\mathrm{H}_{2} \mathrm{O}\right)\right]\left(\mathrm{PF}_{6}\right) .{ }^{24}$ The analogous nickel(II) complex $\left[\mathrm{Ni}_{2}\left(\mathrm{CH}_{3} \mathrm{H}_{2} \mathbf{L 1}\right)\left(\mathrm{CH}_{3} \mathrm{COO}\right)_{2}\right]\left(\mathrm{PF}_{6}\right) \cdot 0.5 \mathrm{H}_{2} \mathrm{O}$ has been reported and in that case the two alkoxide arms are protonated, with the two nickel(II) sites bridged by two acetato ligands. ${ }^{34}$

X-ray structural data were obtained for two other complexes, bearing tetranuclear (dimer of dimers) structures, $\left[\mathrm{Zn}_{4}(\mathrm{BrL2})_{2}\left(\mathrm{PO}_{3} \mathrm{~F}\right)_{2}\left(\mathrm{H}_{2} \mathrm{O}\right)_{2}\right]\left(\mathrm{PF}_{6}\right)_{2}$ and $\left[\mathrm{Zn}_{4}\left(\mathrm{CH}_{3} \mathbf{L} 2\right)_{2}\left(\mathrm{NO}_{2} \mathrm{C}_{6} \mathrm{H}_{5}\right.\right.$ $\left.\left.\mathrm{OPO}_{3}\right)_{2} \quad\left(\mathrm{H}_{2} \mathrm{O}\right)_{2}\right]\left(\mathrm{PF}_{6}\right)_{2}$. For $\left[\mathrm{Zn}_{4}(\mathrm{BrL2})_{2}\left(\mathrm{PO}_{3} \mathrm{~F}\right)_{2}\left(\mathrm{H}_{2} \mathrm{O}\right)_{2}\right]\left(\mathrm{PF}_{6}\right)_{2}$ each dimer is composed of a $\left[\mathrm{Zn}_{2}(\mathrm{BrL2})\right]^{+}$fragment, the metal ions in each fragment $\mathrm{Zn}(1) / \mathrm{Zn}(2)$ and $\mathrm{Zn}(3) / \mathrm{Zn}(4)$ separated by $3.724 \AA$ and $3.572 \AA$, respectively. The two $\mathrm{PO}_{3} \mathrm{~F}^{2-}$ anions display a $\mu_{3} \eta^{3}$ coordination mode ${ }^{35}$ and complete the coordination sphere for $\mathrm{Zn}(3)$ and $\mathrm{Zn}(4)$ such that two of the oxygen donors of 


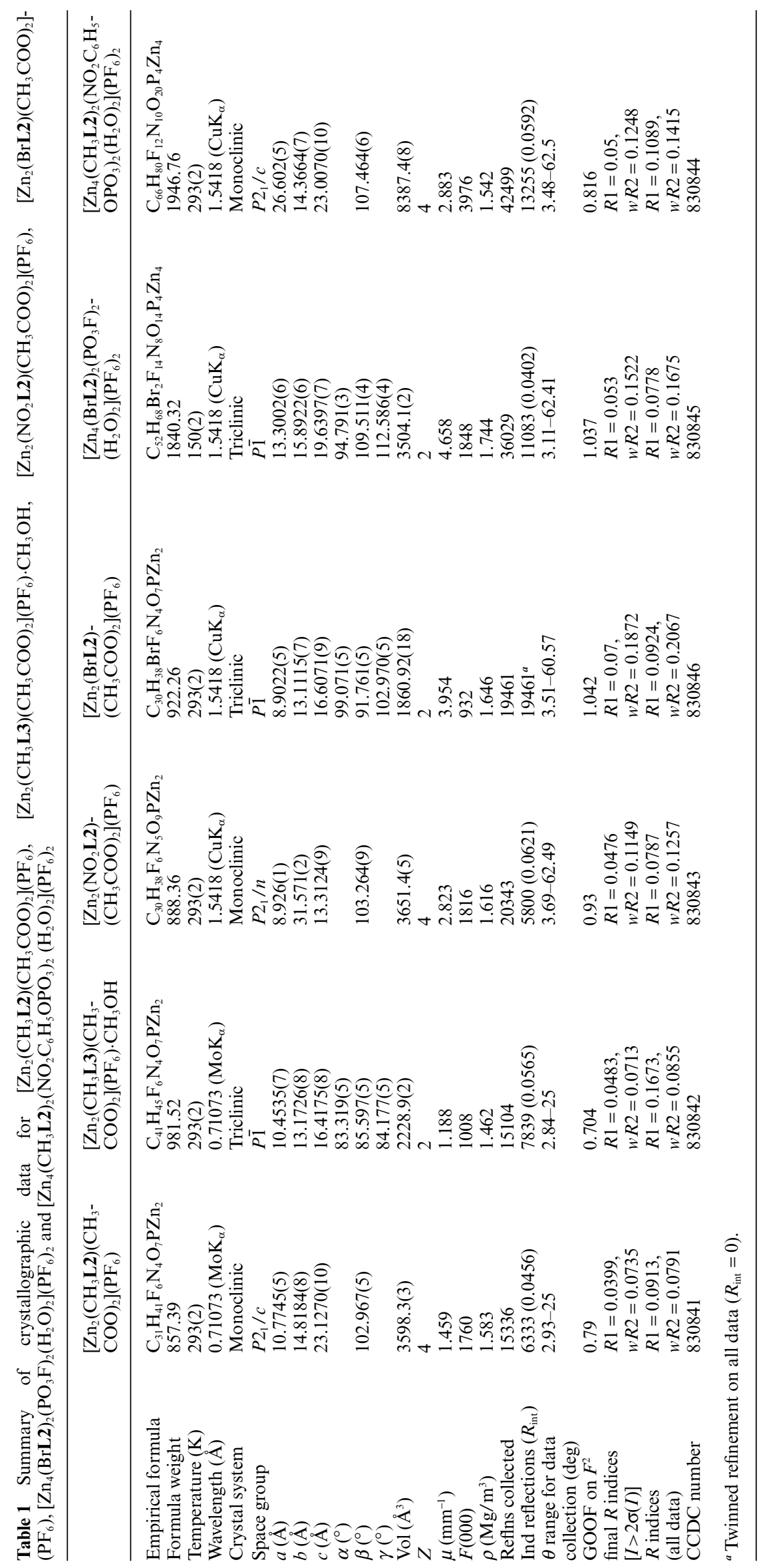


Table 2 Selected bond lengths $(\AA)$ and angles $\left({ }^{\circ}\right)$ for $\left[\mathrm{Zn}_{2}\left(\mathrm{CH}_{3} \mathbf{L} 2\right)\left(\mathrm{CH}_{3} \mathrm{COO}\right)_{2}\right]\left(\mathrm{PF}_{6}\right), \quad\left[\mathrm{Zn}_{2}\left(\mathrm{CH}_{3} \mathbf{L 3}\right)\left(\mathrm{CH}_{3} \mathrm{COO}_{2}\right]\left(\mathrm{PF}_{6}\right) \cdot \mathrm{CH}_{3} \mathrm{OH}\right.$ and $\left[\mathrm{Zn}_{2}\left(\mathrm{NO}_{2} \mathbf{L 2}\right)\left(\mathrm{CH}_{3} \mathrm{COO}\right)_{2}\right]\left(\mathrm{PF}_{6}\right),\left[\mathrm{Zn}_{2}(\mathrm{BrL2})\left(\mathrm{CH}_{3} \mathrm{COO}\right)_{2}\right]\left(\mathrm{PF}_{6}\right)$

\begin{tabular}{|c|c|c|c|c|}
\hline & $\begin{array}{l}{\left[\mathrm{Zn}_{2}\left(\mathrm{CH}_{3} \mathbf{L} 2\right)-\right.} \\
\left.\left(\mathrm{CH}_{3} \mathrm{COO}\right)_{2}\right]\left(\mathrm{PF}_{6}\right)\end{array}$ & $\begin{array}{l}{\left[\mathrm{Zn}_{2}\left(\mathrm{CH}_{3} \mathbf{L 3}\right)\left(\mathrm{CH}_{3} \mathrm{COO}\right)_{2}\right]-} \\
\left(\mathrm{PF}_{6}\right) \cdot \mathrm{CH}_{3} \mathrm{OH}\end{array}$ & $\begin{array}{l}{\left[\mathrm{Zn}_{2}\left(\mathrm{NO}_{2} \mathbf{L 2}\right)-\right.} \\
\left.\left(\mathrm{CH}_{3} \mathrm{COO}\right)_{2}\right]\left(\mathrm{PF}_{6}\right)\end{array}$ & $\begin{array}{l}{\left[\mathrm{Zn}_{2}(\mathrm{BrL2})-\right.} \\
\left.\left(\mathrm{CH}_{3} \mathrm{COO}\right)_{2}\right]\left(\mathrm{PF}_{6}\right)\end{array}$ \\
\hline $\mathrm{Zn}(1)-\mathrm{O}(1)$ & $2.006(2)$ & $2.003(3)$ & $2.043(3)$ & $2.007(3)$ \\
\hline $\mathrm{Zn}(1)-\mathrm{O}(2)$ & $2.049(3)$ & $1.979(3)$ & $1.992(3)$ & $2.000(4)$ \\
\hline $\mathrm{Zn}(1)-\mathrm{O}(5)$ & $2.397(3)$ & & $2.380(4)$ & $2.433(4)$ \\
\hline $\mathrm{Zn}(1)-\mathrm{O}(6)$ & $1.997(3)$ & $2.044(3)$ & $2.055(3)$ & $2.067(3)$ \\
\hline $\mathrm{Zn}(1)-\mathrm{N}(3)$ & $2.184(3)$ & $2.200(4)$ & $2.193(3)$ & $2.196(4)$ \\
\hline $\mathrm{Zn}(1)-\mathrm{N}(4)$ & $2.123(3)$ & $2.108(4)$ & $2.134(4)$ & $2.114(4)$ \\
\hline $\mathrm{Zn}(2)-\mathrm{O}(1)$ & $2.024(3)$ & $2.024(3)$ & $2.041(3)$ & $2.020(3)$ \\
\hline $\mathrm{Zn}(2)-\mathrm{O}(3)$ & $1.992(2)$ & $2.021(3)$ & $2.076(3)$ & $2.068(4)$ \\
\hline $\mathrm{Zn}(2)-\mathrm{O}(4)$ & $2.467(3)$ & & $2.323(3)$ & $2.368(4)$ \\
\hline $\mathrm{Zn}(2)-\mathrm{O}(7)$ & $2.076(3)$ & $1.982(4)$ & $1.997(3)$ & $1.991(3)$ \\
\hline $\mathrm{Zn}(2)-\mathrm{N}(1)$ & $2.188(3)$ & $2.187(4)$ & $2.197(3)$ & $2.206(4)$ \\
\hline $\mathrm{Zn}(2)-\mathrm{N}(2)$ & $2.148(3)$ & $2.123(4)$ & $2.129(4)$ & $2.127(4)$ \\
\hline $\mathrm{Zn}(1) \ldots \mathrm{Zn}(2)$ & 3.296 & 3.247 & 3.341 & 3.304 \\
\hline $\mathrm{O}(1)-\mathrm{Zn}(1)-\mathrm{O}(2)$ & $91.69(11)$ & $95.65(14)$ & $98.64(13)$ & $97.86(14)$ \\
\hline $\mathrm{O}(1)-\mathrm{Zn}(1)-\mathrm{O}(5)$ & $89.46(10)$ & & $91.72(13)$ & $91.14(15)$ \\
\hline $\mathrm{O}(1)-\mathrm{Zn}(1)-\mathrm{O}(6)$ & $99.21(11)$ & $95.01(13)$ & $91.30(13)$ & $92.35(14)$ \\
\hline $\mathrm{O}(1)-\mathrm{Zn}(1)-\mathrm{N}(3)$ & $91.24(11)$ & $89.34(16)$ & $89.11(11)$ & $89.66(13)$ \\
\hline $\mathrm{O}(1)-\mathrm{Zn}(1)-\mathrm{N}(4)$ & $167.50(13)$ & $167.69(17)$ & $167.04(13)$ & $167.80(16)$ \\
\hline $\mathrm{N}(3)-\mathrm{Zn}(1)-\mathrm{N}(4)$ & $77.71(13)$ & $78.48(19)$ & $78.24(13)$ & $78.25(15)$ \\
\hline $\mathrm{O}(1)-\mathrm{Zn}(2)-\mathrm{O}(3)$ & $100.72(11)$ & $93.12(12)$ & $92.03(13)$ & $91.79(14)$ \\
\hline $\mathrm{O}(1)-\mathrm{Zn}(2)-\mathrm{O}(4)$ & $88.43(10)$ & & $93.56(12)$ & $95.33(14)$ \\
\hline $\mathrm{O}(1)-\mathrm{Zn}(2)-\mathrm{O}(7)$ & $92.69(11)$ & $97.80(14)$ & $98.56(12)$ & $99.09(13)$ \\
\hline $\mathrm{O}(1)-\mathrm{Zn}(2)-\mathrm{N}(1)$ & $88.93(10)$ & $89.24(15)$ & $88.77(11)$ & $89.33(13)$ \\
\hline $\mathrm{O}(1)-\mathrm{Zn}(2)-\mathrm{N}(2)$ & $167.01(11)$ & $167.12(17)$ & $166.63(13)$ & $166.91(15)$ \\
\hline $\mathrm{N}(1)-\mathrm{Zn}(2)-\mathrm{N}(2)$ & $78.08(12)$ & $78.02(18)$ & $77.88(14)$ & $77.66(16)$ \\
\hline $\mathrm{Zn}(1)-\mathrm{O}(1)-\mathrm{Zn}(2)$ & $109.70(11)$ & $107.49(16)$ & 109.73(13) & $110.21(14)$ \\
\hline
\end{tabular}

the anion are bidentate $(\mathrm{Zn}(3)-\mathrm{O}(3 \mathrm{~B}) 2.099(4) \AA$, $\mathrm{Zn}(3)-\mathrm{O}(6 \mathrm{~B})$

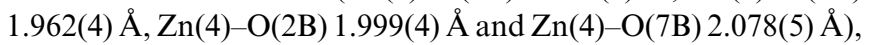
with the remaining oxygen donors coordinated monodentately to the other zinc(II) pair ( $\mathrm{Zn}(1)-\mathrm{O}(3 \mathrm{~A}) 2.015(4) \AA$ and $\mathrm{Zn}(2)-\mathrm{O}(7 \mathrm{~A})$ 2.024(4) A). The coordination spheres of $\mathrm{Zn}(1)$ and $\mathrm{Zn}(2)$ are completed by a terminal water molecule coordinated to each metal atom, $\mathrm{Zn}(2)-\mathrm{O}(2 \mathrm{~A}) 2.083(4) \AA$ and $\mathrm{Zn}(1)-\mathrm{O}(6 \mathrm{~A}) 2.086(4)$ $\AA$. The assignment of the $\mathrm{PO}_{3} \mathrm{~F}^{2-}$ is based on the overall charge of the molecule, the $\mathrm{P}-\mathrm{F}$ bond versus $\mathrm{P}-\mathrm{O}$ bond distances $(\mathrm{P}-\mathrm{O}($ av. $)$

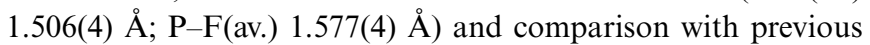
examples (P-F(av.) 1.568(2) $\AA$ ).$^{36-38}$ The $\mathrm{PO}_{3} \mathrm{~F}^{2-}$ arose presumably from hydrolysis of the hexafluorophosphate on standing in aqueous solution. The presence of apparent hydrolysis products of $\mathrm{NaPF}_{6}$ is not without precedent as in a previous study we characterized a zinc(II) complex with the $\mathrm{PO}_{4}{ }^{3-}$ anion arising as an impurity in the $\mathrm{NaPF}_{6}$ sample. ${ }^{39}$

The crystallization of the $\left[\mathrm{Zn}_{4}\left(\mathrm{CH}_{3} \mathbf{L 2}\right)_{2}\left(\mathrm{NO}_{2} \mathrm{C}_{6} \mathrm{H}_{5} \mathrm{OPO}_{3}\right)_{2}\right.$ $\left.\left(\mathrm{H}_{2} \mathrm{O}\right)_{2}\right]\left(\mathrm{PF}_{6}\right)_{2}$ complex arose from a deliberate attempt to probe the structure of a substrate-bound complex using BPNPP as a slow substrate. The resulting complex contained PNPP, a hydrolysis product of the initial substrate. Each dimer is composed of a $\left[\mathrm{Zn}_{2}\left(\mathrm{CH}_{3} \mathbf{L 2}\right)\right]^{+}$fragment, the metal ion separation $\mathrm{Zn}(1) / \mathrm{Zn}(2)$ and $\mathrm{Zn}(3) / \mathrm{Zn}(4)$ being $3.747 \AA$ and $3.521 \AA$, respectively. Again, the $\mathrm{NO}_{2} \mathrm{C}_{6} \mathrm{H}_{5} \mathrm{OPO}_{3}{ }^{-}$moiety has a $\mu_{3} \eta^{3}$ coordination mode ${ }^{35}$ and completes the coordination spheres with bidentate coordination to one pair of $\mathrm{Zn}$ (II) ions ( $\mathrm{Zn}(3)$ $\mathrm{O}(3 \mathrm{~B}) 2.082(3) \AA, \mathrm{Zn}(4)-\mathrm{O}(2 \mathrm{~B})$ 1.993(3) $\AA$ and $\mathrm{Zn}(3)-\mathrm{O}(6 \mathrm{~B})$ 1.982(4) $\AA$ and $\mathrm{Zn}(4)-\mathrm{O}(7 \mathrm{~B}) 2.065(4) \AA$ ) and monodentate coordination to the other zinc(II) pair ( $\mathrm{Zn}(1)-\mathrm{O}(6 \mathrm{~A}) 2.001(4) \AA$ and $\mathrm{Zn}(2)-\mathrm{O}(2 \mathrm{~A}) 2.011(4) \AA)$. The coordination spheres of $\mathrm{Zn}(1 \mathrm{~A})$ and $\mathrm{Zn}(2 \mathrm{~A})$ are completed by terminal aqua ligands, $\mathrm{Zn}(1)-$
$\mathrm{O}(3 \mathrm{~A}), 2.080(3) \AA$ and $\mathrm{Zn}(2)-\mathrm{O}$ (7A) 2.128(3) $\AA$. Other relevant bond distances and angles for $\left[\mathrm{Zn}_{4}(\mathrm{BrL2})_{2}\left(\mathrm{PO}_{3} \mathrm{~F}\right)_{2}\left(\mathrm{H}_{2} \mathrm{O}\right)_{2}\right]\left(\mathrm{PF}_{6}\right)_{2}$ and $\left[\mathrm{Zn}_{4}\left(\mathrm{CH}_{3} \mathrm{L2}\right)_{2}\left(\mathrm{NO}_{2} \mathrm{C}_{6} \mathrm{H}_{5} \mathrm{OPO}_{3}\right)_{2}\left(\mathrm{H}_{2} \mathrm{O}\right)_{2}\right]\left(\mathrm{PF}_{6}\right)_{2}$ are reported in Table 3. The bridged structure of the phosphate esters is typical of other similar reported structures of di-zinc(II) complexes with bridging phosphate esters, dibenzyl phosphate, ${ }^{40}$ diphenyl phosphate ${ }^{41}$ and bis(4-nitrophenyl)phosphate. ${ }^{42}$ In terms of the relevance to the catalytic studies (vide infra) the structure of $\left[\mathrm{Zn}_{4}\left(\mathrm{CH}_{3} \mathbf{L 2}\right)_{2}\left(\mathrm{NO}_{2} \mathrm{C}_{6} \mathrm{H}_{5} \mathrm{OPO}_{3}\right)_{2}\left(\mathrm{H}_{2} \mathrm{O}\right)_{2}\right]\left(\mathrm{PF}_{6}\right)_{2}$, in line with previous studies, ${ }^{41}$ suggests that in these di-zinc(II) complexes bidentate coordination of substrate occurs.

\section{Mass spectrometry}

Mass spectral analysis, determined in both methanol and $\mathrm{H}_{2} \mathrm{O}: \mathrm{MeCN}(1: 1)$, shows that the complexes exist as dinuclear zinc species with the isotopic patterns for $\mathrm{Zn}(\mathrm{II})_{2}$ species being distinctly different from that observed for a monozinc species. ${ }^{24}$ In methanol the complex with $\mathrm{CH}_{3} \mathrm{HL2}$ shows acetate present $\left(\left[\mathrm{Zn}\left(\mathrm{CH}_{3} \mathbf{L 2}\right)\left(\mathrm{CH}_{3} \mathrm{COO}\right)_{2}\right]^{+}\right.$, $\operatorname{exp~} \mathrm{m} / \mathrm{z}$ 711.20; calc. $\mathrm{m} / z 711.15(99.9 \%), 713.15(100 \%))$. Loss of acetate is considered a prerequisite for formation of the catalytically relevant species in solution. ${ }^{43-46}$ Under the conditions employed for the catalytic studies $\left(\mathrm{H}_{2} \mathrm{O}: \mathrm{MeCN}, 1: 1\right)$ and in the presence of the slow substrate PNPP (the latter a hydrolysis product of BPNPP) the mass spectrum showed the presence of a tetrameric species $\left[\mathrm{Zn}_{4}\left(\mathrm{CH}_{3} \mathbf{L 2}\right)_{2}(\mathrm{PNPP})_{2}(\mathrm{OH})\left(\mathrm{H}_{2} \mathrm{O}\right)\right]^{+}(\operatorname{exp~} \mathrm{m} / \mathrm{z}$ 1659.14; calc. $m / z 1657.22(100 \%), 1659.22(87 \%))$, a dimeric species $\left[\mathrm{Zn}_{2}\left(\mathrm{CH}_{3} \mathbf{L 2}\right)(\mathrm{PNPP})_{2}+2 \mathrm{H}\right]^{+}(\operatorname{exp~} \mathrm{m} / z$ 1031.08; calc. $\mathrm{m} / z$ $1031.10(100 \%))$ as well as $\left[\mathrm{Zn}_{2}\left(\mathrm{CH}_{3} \mathbf{L 2}\right)(\mathrm{PNPP})\right]^{+}(\exp m / z$ 811.4; calc. $m / z 810.1(97 \%), m / z 812.1(100 \%))$. Species such as 
$\left[\mathrm{Zn}_{2}\left(\mathrm{CH}_{3} \mathbf{L} 2\right)\left(\mathrm{CH}_{3} \mathrm{COO}\right)_{2}\right]\left(\mathrm{PF}_{6}\right)$

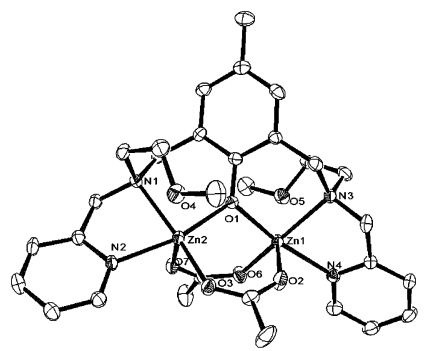

$\left[\mathrm{Zn}_{2}\left(\mathrm{CH}_{3} \mathbf{L} 3\right)\left(\mathrm{CH}_{3} \mathrm{COO}\right)_{2}\right]\left(\mathrm{PF}_{6}\right) \cdot \mathrm{CH}_{3} \mathrm{OH}$

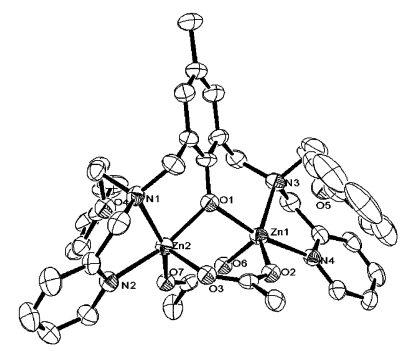

$\left[\mathrm{Zn}_{4}\left(\mathrm{CH}_{3} \mathbf{L 2}\right)_{2}\left(\mathrm{NO}_{2} \mathrm{C}_{6} \mathrm{H}_{5} \mathrm{OPO}_{3}\right)_{2}\left(\mathrm{H}_{2} \mathrm{O}\right)_{2}\right]\left(\mathrm{PF}_{6}\right)_{2}$

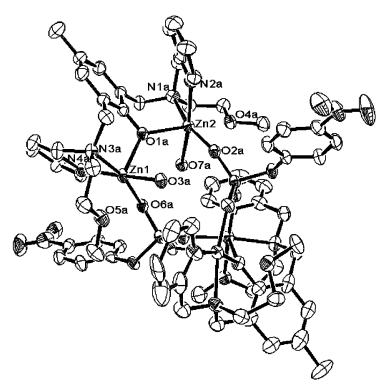

$\left[\mathrm{Zn}_{2}\left(\mathrm{NO}_{2} \mathrm{~L} 2\right)\left(\mathrm{CH}_{3} \mathrm{COO}\right)_{2}\right]\left(\mathrm{PF}_{6}\right)$

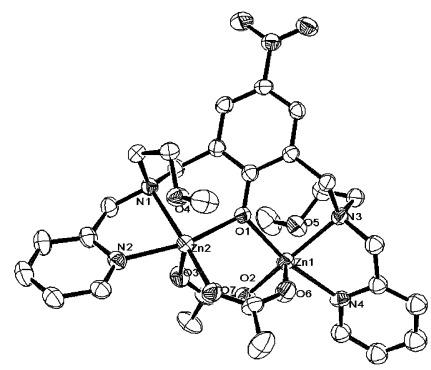

$\left[\mathrm{Zn}_{2}(\mathrm{BrL2})\left(\mathrm{CH}_{3} \mathrm{COO}\right)_{2}\right]\left(\mathrm{PF}_{6}\right)$

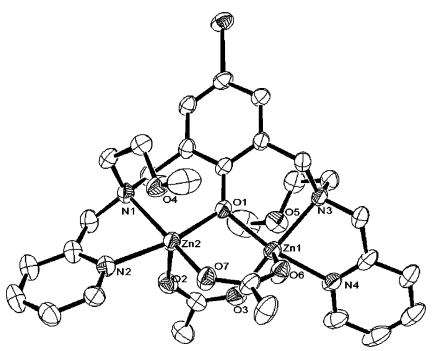

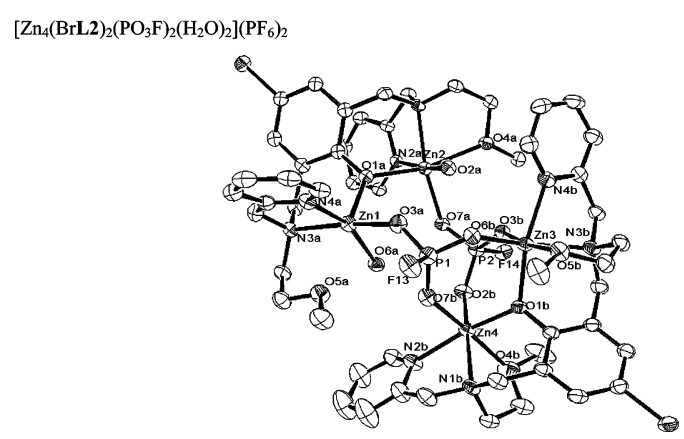

Fig. 1 ORTEP plots of $\left[\mathrm{Zn}_{2}\left(\mathrm{CH}_{3} \mathbf{L 2}\right)\left(\mathrm{CH}_{3} \mathrm{COO}\right)_{2}\right]\left(\mathrm{PF}_{6}\right),\left[\mathrm{Zn}_{2}\left(\mathrm{CH}_{3} \mathbf{L} 3\right)\left(\mathrm{CH}_{3} \mathrm{COO}\right)_{2}\right]\left(\mathrm{PF}_{6}\right) \cdot \mathrm{CH}_{3} \mathrm{OH},\left[\mathrm{Zn}_{2}\left(\mathrm{NO}_{2} \mathbf{L} 2\right)\left(\mathrm{CH}_{3} \mathrm{COO}\right)_{2}\right]\left(\mathrm{PF}_{6}\right),\left[\mathrm{Zn}_{2}(\mathrm{BrL2})\left(\mathrm{CH}_{3}-\right.\right.$ $\left.\mathrm{COO})_{2}\right]\left(\mathrm{PF}_{6}\right),\left[\mathrm{Zn}_{4}\left(\mathrm{CH}_{3} \mathbf{L} 2\right)_{2}\left(\mathrm{NO}_{2} \mathrm{C}_{6} \mathrm{H}_{5} \mathrm{OPO}_{3}\right)_{2}\left(\mathrm{H}_{2} \mathrm{O}\right)_{2}\right]\left(\mathrm{PF}_{6}\right)_{2}$ and $\left[\mathrm{Zn}_{4}(\mathrm{BrL2})_{2}\left(\mathrm{PO}_{3} \mathrm{~F}\right)_{2}\left(\mathrm{H}_{2} \mathrm{O}\right)_{2}\right]\left(\mathrm{PF}_{6}\right)_{2}$ with $25 \%$ probability level of thermal ellipsoids. Hydrogen atoms, counter ions and non-coordinated solvent molecules have been omitted for clarity, as have carbon atom labels.

$\left[\mathrm{Zn}_{2}\left(\mathrm{CH}_{3} \mathbf{L 2}\right)(\mathrm{HCOO})-\mathrm{H}\right]^{+}(\exp m / z$ 639.4; calc. $m / z$ 637.1 $(98 \%)$ $m / z 639.1(100 \%))$ and $\left[\mathrm{Zn}_{2}\left(\mathrm{CH}_{3} \mathbf{L 2}\right)(\mathrm{HCOO})_{2}\right]^{+}(\operatorname{exp~} m / z$ 684.4; calc. $m / z 683.1(98 \%), m / z 685.1(100 \%))$ are also present. The formate ion is commonly found in the mass spectra of these types of complexes ${ }^{39,47}$ arising either from fragmentation of the acetate ion or adventitiously from the instrument. In the presence of BPNPP, again in a mixed $\mathrm{H}_{2} \mathrm{O}: \mathrm{MeCN}(1: 1)$ solvent system, the mass spec- trum shows the presence of $\left[\mathrm{Zn}_{2}\left(\mathrm{CH}_{3} \mathbf{L 2}\right)(\mathrm{BPNPP})\left(\mathrm{H}_{2} \mathrm{O}\right)\left(\mathrm{OCH}_{3}\right)\right]^{+}$ (exp $m / z$ 979.1; calc. $m / z$ 981.1 (96\%), $m / z$ 983.1 (100\%)) as well as evidence of BPNPP hydrolysis products $\left[\mathrm{Zn}_{2}\left(\mathrm{CH}_{3} \mathbf{L 2}\right)(\mathrm{PNPP})\right]^{+}$ ( $\exp m / z$ 811.4; calc. $m / z$ 810.1 (97\%), $m / z 812.1(100 \%)$ ) suggesting that under the conditions of the experiment the complex is able to hydrolyze BPNPP. In addition, in each case under the conditions of the mass spectral measurements, the predominant 
Table 3 Selected bond lengths $(\AA)$ and angles $\left({ }^{\circ}\right)$ for $\left[\mathrm{Zn}_{4}(\mathrm{BrL2})_{2}\right.$ $\left.\left(\mathrm{PO}_{3} \mathrm{~F}\right)_{2}\left(\mathrm{H}_{2} \mathrm{O}\right)_{2}\right]\left(\mathrm{PF}_{6}\right)_{2}$ and $\left[\mathrm{Zn}_{4}\left(\mathrm{CH}_{3} \mathbf{L} 2\right)_{2}\left(\mathrm{NO}_{2} \mathrm{C}_{6} \mathrm{H}_{5} \mathrm{OPO}_{3}\right)_{2}\left(\mathrm{H}_{2} \mathrm{O}\right)_{2}\right]\left(\mathrm{PF}_{6}\right)_{2}$

\begin{tabular}{|c|c|c|}
\hline & $\begin{array}{l}{\left[\mathrm{Zn}_{4}(\mathrm{BrL2})_{2}\left(\mathrm{PO}_{3} \mathrm{~F}\right)_{2}-\right.} \\
\left.\left(\mathrm{H}_{2} \mathrm{O}\right)_{2}\right]\left(\mathrm{PF}_{6}\right)_{2}\end{array}$ & $\begin{array}{l}{\left[\mathrm{Zn}_{4}\left(\mathrm{CH}_{3} \mathbf{L 2}\right)_{2}\left(\mathrm{NO}_{2} \mathrm{C}_{6} \mathrm{H}_{5}-\right.\right.} \\
\left.\left.\mathrm{OPO}_{3}\right)_{2}\left(\mathrm{H}_{2} \mathrm{O}\right)_{2}\right]\left(\mathrm{PF}_{6}\right)_{2}\end{array}$ \\
\hline $\mathrm{Zn}(1)-\mathrm{O}(6 \mathrm{~A})$ & $2.086(4)$ & $2.001(4)$ \\
\hline $\mathrm{Zn}(1)-\mathrm{O}(1 \mathrm{~A})$ & $2.028(4)$ & $2.065(4)$ \\
\hline $\mathrm{Zn}(1)-\mathrm{O}(3 \mathrm{~A})$ & $2.015(4)$ & $2.080(3)$ \\
\hline $\mathrm{Zn}(1)-\mathrm{N}(4 \mathrm{~A})$ & $2.118(5)$ & $2.111(4)$ \\
\hline $\mathrm{Zn}(1)-\mathrm{N}(3 \mathrm{~A})$ & $2.164(5)$ & $2.154(4)$ \\
\hline $\mathrm{Zn}(2)-\mathrm{O}(2 \mathrm{~A})$ & $2.083(4)$ & $2.011(4)$ \\
\hline $\mathrm{Zn}(2)-\mathrm{O}(1 \mathrm{~A})$ & $2.159(4)$ & $2.096(3)$ \\
\hline $\mathrm{Zn}(2)-\mathrm{O}(7 \mathrm{~A})$ & $2.024(4)$ & $2.128(3)$ \\
\hline $\mathrm{Zn}(2)-\mathrm{N}(2 \mathrm{~A})$ & $2.114(4)$ & $2.129(5)$ \\
\hline $\mathrm{Zn}(2)-\mathrm{N}(1 \mathrm{~A})$ & $2.156(4)$ & $2.164(5)$ \\
\hline $\mathrm{Zn}(2)-\mathrm{O}(4 \mathrm{~A})$ & $2.296(4)$ & $2.374(4)$ \\
\hline $\mathrm{Zn}(3)-\mathrm{O}(6 \mathrm{~B})$ & $1.962(4)$ & $1.982(4)$ \\
\hline $\mathrm{Zn}(3)-\mathrm{O}(1 \mathrm{~B})$ & $2.057(4)$ & $2.050(4)$ \\
\hline $\mathrm{Zn}(3)-\mathrm{O}(3 \mathrm{~B})$ & $2.099(4)$ & $2.082(3)$ \\
\hline $\mathrm{Zn}(3)-\mathrm{N}(3 \mathrm{~B})$ & $2.165(6)$ & $2.170(5)$ \\
\hline $\mathrm{Zn}(3)-\mathrm{N}(4 \mathrm{~B})$ & $2.173(5)$ & $2.184(6)$ \\
\hline $\mathrm{Zn}(3)-\mathrm{O}(5 \mathrm{~B})$ & $2.269(4)$ & $2.262(4)$ \\
\hline $\mathrm{Zn}(4)-\mathrm{O}(2 \mathrm{~B})$ & $1.999(4)$ & $1.993(3)$ \\
\hline $\mathrm{Zn}(4)-\mathrm{O}(1 \mathrm{~B})$ & $2.054(4)$ & $2.013(4)$ \\
\hline $\mathrm{Zn}(4)-\mathrm{O}(7 \mathrm{~B})$ & $2.078(5)$ & $2.065(4)$ \\
\hline $\mathrm{Zn}(4)-\mathrm{N}(2 \mathrm{~B})$ & $2.159(6)$ & $2.126(6)$ \\
\hline $\mathrm{Zn}(4)-\mathrm{N}(1 \mathrm{~B})$ & $2.182(5)$ & $2.202(5)$ \\
\hline $\mathrm{Zn}(4)-\mathrm{O}(4 \mathrm{~B})$ & $2.285(5)$ & $2.389(4)$ \\
\hline $\mathrm{O}(1 \mathrm{~A})-\mathrm{Zn}(1)-\mathrm{N}(4 \mathrm{~A})$ & $108.47(17)$ & $93.61(16)$ \\
\hline $\mathrm{O}(1 \mathrm{~A})-\mathrm{Zn}(1)-\mathrm{N}(3 \mathrm{~A})$ & $93.55(17)$ & $93.81(18)$ \\
\hline $\mathrm{N}(4 \mathrm{~A})-\mathrm{Zn}(1)-\mathrm{N}(3 \mathrm{~A})$ & $79.95(19)$ & $80.01(18)$ \\
\hline $\mathrm{N}(2 \mathrm{~A})-\mathrm{Zn}(2)-\mathrm{N}(1 \mathrm{~A})$ & $80.38(17)$ & $80.2(2)$ \\
\hline $\mathrm{N}(2 \mathrm{~A})-\mathrm{Zn}(2)-\mathrm{O}(1 \mathrm{~A})$ & $87.13(16)$ & $90.71(16)$ \\
\hline $\mathrm{N}(1 \mathrm{~A})-\mathrm{Zn}(2)-\mathrm{O}(1 \mathrm{~A})$ & $92.02(17)$ & $93.23(17)$ \\
\hline $\mathrm{O}(1 \mathrm{~B})-\mathrm{Zn}(3)-\mathrm{N}(3 \mathrm{~B})$ & $90.11(18)$ & $89.64(19)$ \\
\hline $\mathrm{O}(1 \mathrm{~B})-\mathrm{Zn}(3)-\mathrm{N}(4 \mathrm{~B})$ & $164.7(2)$ & $165.5(2)$ \\
\hline $\mathrm{N}(3 \mathrm{~B})-\mathrm{Zn}(3)-\mathrm{N}(4 \mathrm{~B})$ & $75.6(2)$ & $77.3(2)$ \\
\hline $\mathrm{O}(1 \mathrm{~B})-\mathrm{Zn}(4)-\mathrm{N}(2 \mathrm{~B})$ & $166.47(18)$ & $167.4(2)$ \\
\hline $\mathrm{O}(1 \mathrm{~B})-\mathrm{Zn}(4)-\mathrm{N}(1 \mathrm{~B})$ & $90.36(17)$ & $89.8(2)$ \\
\hline $\mathrm{N}(2 \mathrm{~B})-\mathrm{Zn}(4)-\mathrm{N}(1 \mathrm{~B})$ & $76.8(2)$ & $77.6(2)$ \\
\hline $\mathrm{Zn}(1)-\mathrm{O}(1 \mathrm{~A})-\mathrm{Zn}(2)$ & $125.56(19)$ & $128.4(2)$ \\
\hline $\mathrm{Zn}(4)-\mathrm{O}(1 \mathrm{~B})-\mathrm{Zn}(3)$ & $120.67(19)$ & $120.1(2)$ \\
\hline
\end{tabular}

species is the $\left[\mathrm{Zn}_{2}\left(\mathrm{CH}_{3} \mathbf{L 2}\right)\right]^{n+}$ complex and substrate, the acetate anions not being present.

\section{NMR solution studies}

When one equivalent of zinc(II) acetate was added to a $\mathrm{CD}_{3} \mathrm{CN}$ solution of the ligand $\mathrm{CH}_{3} \mathrm{HL} 2$ the resonances in the aromatic region of the ${ }^{1} \mathrm{H}$ NMR spectrum exhibited a downfield shift. The spectrum showed the presence of free ligand and signals identical to the spectrum when a second equivalent of zinc(II) acetate was added. Thus the spectrum with one equivalent zinc(II) added showed that only free ligand and ligand with two zinc ions coordinated are present, suggesting that the acetates support a cooperative binding of two zinc ions simultaneously to the ligand. In the NMR spectrum with two equivalents of zinc a second set of low intensity signals, but at higher field, was detected (also present in the spectrum with one equivalent but partially overlapping with free ligand signals) indicative of a minor, but different, isomeric form. To investigate possible temperature effects, the NMR spectrum of the complex was recorded at four different temperatures (298, 316, 333 and $343 \mathrm{~K}$; Fig. 2)). The intensities of the resonances were temperature-dependent; at higher temperature the higher field less intense signals gained intensity. The process was reversible upon cooling of the sample. The same

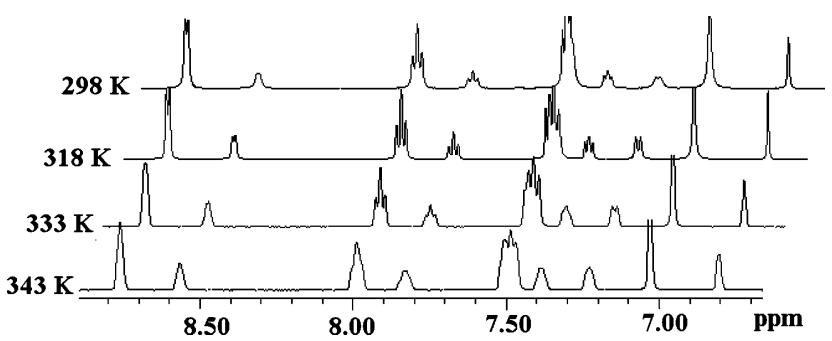

Fig. $2{ }^{1} \mathrm{H}$ NMR spectra of the aromatic region for $\left[\mathrm{Zn}_{2}\left(\mathrm{CH}_{3} \mathbf{L 2}\right)\left(\mathrm{CH}_{3}\right.\right.$ $\left.\mathrm{COO})_{2}\right]\left(\mathrm{PF}_{6}\right)$ in $\mathrm{CD}_{3} \mathrm{CN}$ at four different temperatures.

observation was made for the complex with the $\mathrm{CH}_{3} \mathrm{HL3}$ ligand although in this case the higher field signals were more intense at room temperature, again gaining intensity upon increasing the temperature of the sample. The second set of resonances for both complexes could thus be assigned to either (i) a reversible interchange of the two geometric forms, either syn- or anti- with respect to the plane of the aromatic ring, or (ii) to a species with only partially coordinated ether $\left(-\mathrm{OCH}_{3}\right.$ or $\left.-\mathrm{OPh}\right)$ arms in solution. The interchange of syn- and anti-forms would involve a process necessitating inversion at the tertiary nitrogen donor. On replacing the $\mathrm{CD}_{3} \mathrm{CN}$ solvent with $\left(\mathrm{CD}_{3}\right)_{2} \mathrm{SO}$ the apparent equilibrium position in solution was shifted, with the higher field resonances becoming relatively more intense. In terms of the donor number, DMSO would be expected to coordinate more strongly than acetonitrile. ${ }^{48-51}$ Consideration of the effect of temperature and solvent coupled with the pronounced effect on the ${ }^{1} \mathrm{H}$ NMR spectrum of replacing methyl- with phenyl-ether donors suggests what is occurring in solution is more likely to be an effect of the loosely bound ether pendants, in line with the solid state structures of these complexes which display long zinc(II)-ether interactions. Interestingly, for $\left[\mathrm{Zn}_{2}\left(\mathrm{CH}_{3} \mathrm{HL1}\right)\left(\mathrm{CH}_{3} \mathrm{COO}\right)\left(\mathrm{H}_{2} \mathrm{O}\right)\right]\left(\mathrm{PF}_{6}\right)$, with $\mathrm{Zn}-$ $\mathrm{O}^{-}$and $\mathrm{Zn}-\mathrm{OH}$ donors, and crystallized as the anti-form, only one set of resonance is reported in the ${ }^{1} \mathrm{H}$ NMR spectrum. ${ }^{24}$

\section{Phosphodiesterase-like activity}

Phosphatase-like activities of the complexes were measured at various $\mathrm{pH}$ values ranging from 5 to 10.5 using the activated substrate BDNPP. The data were consistent with the presence of either one or two protonation equilibria and were thus fit to an equation derived for a monoprotic (eqn (1)) or diprotic (eqn (2)) system. $^{52}$

$$
\begin{gathered}
V_{0}=\frac{V_{\text {max }}}{1+\frac{\left[\mathrm{H}^{+}\right]}{K_{\mathrm{es}}}} \\
V_{0}=\frac{V \text { max }}{1+\frac{\left[\mathrm{H}^{+}\right]}{K_{\mathrm{es}_{1}}}+\frac{K_{\mathrm{es}_{2}}}{\left[\mathrm{H}^{+}\right]}}
\end{gathered}
$$

Here, $V_{0}$ is the initial reaction rate, $V_{\max }$ is the maximum rate with BDNPP as substrate $(5 \mathrm{mM})$, and $K_{\text {es }}\left(=K_{\mathrm{a}}\right)$ is the protonation equilibrium constant relevant to catalysis. The resulting fits and catalytic parameters are shown in Fig. 3 and Table 4, respectively. Most notable were the kinetically relevant $\mathrm{p} K_{\mathrm{a}} \mathrm{s}$ for the complexes with $\mathrm{CH}_{3} \mathrm{HL1}^{2-}, \mathrm{CH}_{3} \mathbf{L 2}^{-}$and $\mathrm{CH}_{3} \mathbf{L 3}^{-}$(6.6; 6.7, 11.0; 7.7, 10.8; respectively). The substrate concentration dependence of catalysis 
Table 4 Kinetic data for $\left[\mathrm{Zn}_{2}\left(\mathrm{CH}_{3} \mathrm{HL1}\right)\left(\mathrm{CH}_{3} \mathrm{COO}\right)_{2}\right]\left(\mathrm{PF}_{6}\right),\left[\mathrm{Zn}_{2}\left(\mathrm{CH}_{3} \mathbf{L} 2\right)\left(\mathrm{CH}_{3} \mathrm{COO}\right)_{2}\right]\left(\mathrm{PF}_{6}\right),\left[\mathrm{Zn}_{2}\left(\mathrm{CH}_{3} \mathbf{L 3}\right)\left(\mathrm{CH}_{3} \mathrm{COO}\right)_{2}\right]\left(\mathrm{PF}_{6}\right),\left[\mathrm{Zn}_{2}\left(\mathrm{NO}_{2} \mathbf{L 2}\right)\left(\mathrm{CH}_{3} \mathrm{COO}\right)_{2}\right]-$ $\left(\mathrm{PF}_{6}\right)$ and $\left[\mathrm{Zn}_{2}(\mathrm{BrL2})\left(\mathrm{CH}_{3} \mathrm{COO}\right)_{2}\right]\left(\mathrm{PF}_{6}\right)$

\begin{tabular}{llcc}
\hline Complex & $k_{\text {cat }}\left(\mathrm{s}^{-1}\right)$ & $K_{\mathrm{m}}(\mathrm{mM})$ & $\mathrm{p} K_{\mathrm{a}}$ \\
\hline$\left[\mathrm{Zn}_{2}\left(\mathrm{CH}_{3} \mathrm{HL1}\right)\left(\mathrm{CH}_{3} \mathrm{COO}\right)_{2}\right]\left(\mathrm{PF}_{6}\right)$ & $1.07 \pm 0.04 \times 10^{-3}$ & $12.5 \pm 7.0$ & 6.6 \\
{$\left[\mathrm{Zn}_{2}\left(\mathrm{CH}_{3} \mathbf{L 2}\right)\left(\mathrm{CH}_{3} \mathrm{COO}\right)_{2}\right]\left(\mathrm{PF}_{6}\right)$} & $5.70 \pm 0.04 \times 10^{-3}$ & $20.8 \pm 5.0$ & 1.0 \\
$\left.\mathrm{Zn}_{2}\left(\mathrm{CH}_{3} \mathbf{L} \mathbf{2}\right)\left(\mathrm{CH}_{3} \mathrm{COO}\right)_{2}\right]\left(\mathrm{PF}_{6}\right)$ & $3.60 \pm 0.04 \times 10^{-3}$ & $18.9 \pm 3.5$ & \\
{$\left[\mathrm{Zn}_{2}\left(\mathrm{NO}_{2} \mathbf{L 2}\right)\left(\mathrm{CH}_{3} \mathrm{COO}\right)_{2}\right]\left(\mathrm{PF}_{6}\right)$} & & 7.7 \\
{$\left[\mathrm{Zn}_{2}(\mathrm{BrL2})\left(\mathrm{CH}_{3} \mathrm{COO}\right)_{2}\right]\left(\mathrm{PF}_{6}\right)$} & $0.76 \pm 0.04 \times 10^{-3}$ & $6.5 \pm 1.4$ & 10.8 \\
& $1.90 \pm 0.04 \times 10^{-3}$ & $7.1 \pm 4.0$ & 6.5 \\
\hline
\end{tabular}

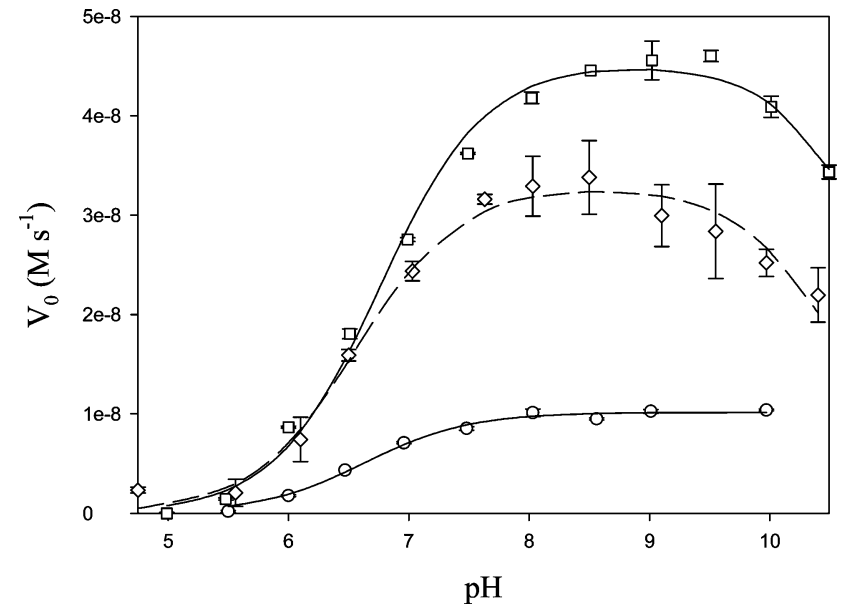

Fig. $3 \mathrm{pH}$ dependence of rate of $\mathrm{BDNPP}$ cleavage by $\left[\mathrm{Zn}_{2}\left(\mathrm{CH}_{3} \mathrm{HL1}\right)\left(\mathrm{CH}_{3} \mathrm{COO}\right)\left(\mathrm{H}_{2} \mathrm{O}\right)\right]\left(\mathrm{PF}_{6}\right)$ $\left(\mathrm{PF}_{6}\right)(\square)$ and $\left[\mathrm{Zn}_{2}\left(\mathrm{CH}_{3} \mathbf{L} 3\right)\left(\mathrm{CH}_{3} \mathrm{COO}\right)_{2}\right]\left(\mathrm{PF}_{6}\right)(\diamond) ; 25^{\circ} \mathrm{C}$; aqueous multi-component buffer (50 mM each of MES, HEPES and CHES), ionic

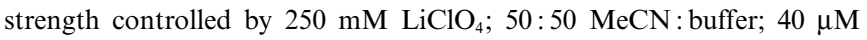
complex; 5 mM BDNPP.

was also measured at $\mathrm{pH} 10.5$ for the $\mathrm{CH}_{3} \mathrm{HL1}^{2-}$ and $\mathrm{pH} 8$ for the $\mathrm{CH}_{3} \mathbf{L 1}^{-}$and $\mathrm{CH}_{3} \mathbf{L 2}^{-}$complexes. Michaelis-Menten type behaviour was observed in each case (Fig. 4) and the data were fit for each complex using non-linear least squares analysis (eqn (3)) to give the Michaelis constant, $V_{\max }$ and $k_{\text {cat }}\left(V_{\max } /\right.$ [complex]) for each complex. ${ }^{52}$

$$
V_{0}=\frac{V_{\max }[S]}{K_{\mathrm{m}}+[S]}
$$

Here, $K_{\mathrm{m}}$ is the Michaelis constant and $[S]$ the substrate concentration. Relevant kinetic data $\left(k_{\mathrm{cat}}, K_{\mathrm{m}}, \mathrm{p} K_{\mathrm{a}}\right)$ are reported in Table 4. For all complexes the rate of hydrolysis of BDNPP (5 mM) was linear for complex concentrations from 20-160 $\mu \mathrm{M}$. The [substrate] and [complex] dependence studies for the di-Zn(II) complexes of $\mathrm{CH}_{3} \mathrm{HL2}$ and $\mathrm{CH}_{3} \mathrm{HL3}$ were carried out at $\mathrm{pH}$ 8.5, for $\mathrm{NO}_{2} \mathrm{HL2} \mathrm{pH} 9.5$ and BrHL2 $\mathrm{pH} 8.8$.

\section{Inductive effects}

The linear plot of $\log _{10}\left(k_{\text {cat }}\right)$ versus $\sigma$, the Hammett parameter, ${ }^{53}$ for the three complexes $\left[\mathrm{Zn}_{2}\left(\mathrm{CH}_{3} \mathbf{L 2}\right)\left(\mathrm{CH}_{3} \mathrm{COO}\right)_{2}\right]\left(\mathrm{PF}_{6}\right) \cdot \mathrm{CH}_{3} \mathrm{OH}$, $\left[\mathrm{Zn}_{2}\left(\mathrm{NO}_{2} \mathbf{L 2}\right)\left(\mathrm{CH}_{3} \mathrm{COO}\right)_{2}\right]\left(\mathrm{PF}_{6}\right)$ and $\left[\mathrm{Zn}_{2}(\mathrm{BrL2})\left(\mathrm{CH}_{3} \mathrm{COO}\right)_{2}\right]-$ $\left(\mathrm{PF}_{6}\right)$ (Fig. 5) suggests that the substituent in the para-position influences the rate of the hydrolysis reaction with the substrate

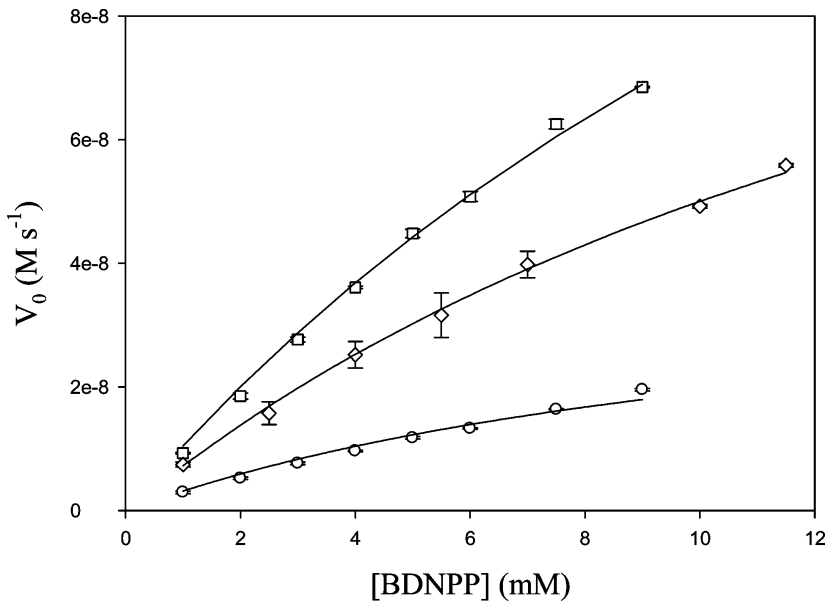

Fig. 4 Substrate concentration dependence for $\left[\mathrm{Zn}_{2}(\mathrm{HL1})\left(\mathrm{CH}_{3} \mathrm{COO}\right)\right.$ $\left.\left(\mathrm{H}_{2} \mathrm{O}\right)\right]\left(\mathrm{PF}_{6}\right)(\mathrm{O})\left[\mathrm{Zn}_{2}\left(\mathrm{CH}_{3} \mathbf{L} 2\right)\left(\mathrm{CH}_{3} \mathrm{COO}\right)_{2}\right]\left(\mathrm{PF}_{6}\right)(\square)$ and $\left[\mathrm{Zn}_{2}\left(\mathrm{CH}_{3} \mathbf{L} \mathbf{3}\right)-\right.$ $\left.\left(\mathrm{CH}_{3} \mathrm{COO}\right)_{2}\right]\left(\mathrm{PF}_{6}\right)(\diamond)$; at $25{ }^{\circ} \mathrm{C}$; aqueous multi-component buffer (50 $\mathrm{mM}$ each of MES, HEPES and CHES), ionic strength controlled by $250 \mathrm{mM} \mathrm{\textrm {LiClO } _ { 4 }} ; 50: 50 \mathrm{MeCN}$ : buffer; $40 \mu \mathrm{M}$ complex.

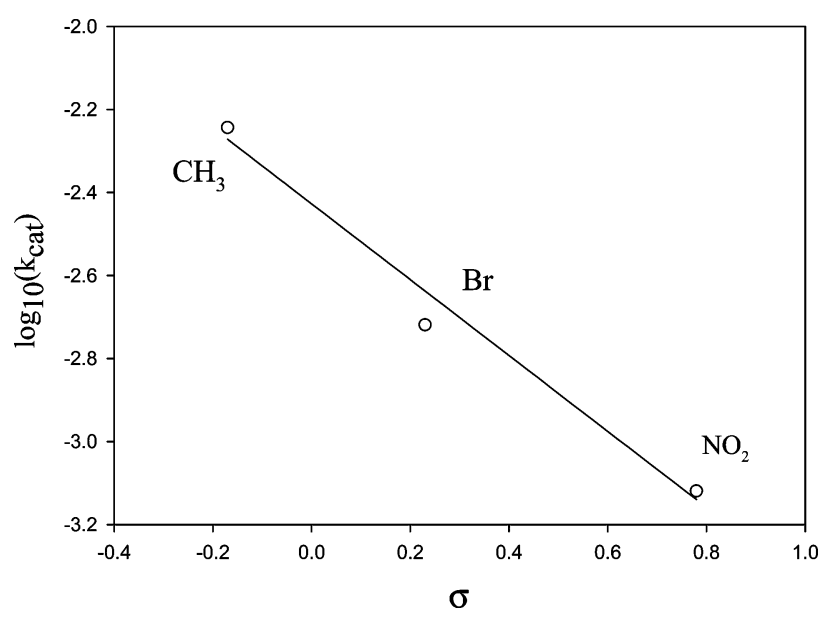

Fig. 5 Linear correlation for the Hammett parameter $(\sigma)$ and $\log _{10}\left(k_{\text {cat }}\right)$ for $\left.\left[\mathrm{Zn}_{2}\left(\mathrm{CH}_{3} \mathbf{L 2}\right)\left(\mathrm{CH}_{3} \mathrm{COO}\right)_{2}\right]\left(\mathrm{PF}_{6}\right), \mathrm{Zn}_{2}\left(\mathrm{NO}_{2} \mathbf{L 2}\right)\left(\mathrm{CH}_{3} \mathrm{COO}\right)_{2}\right]\left(\mathrm{PF}_{6}\right)$ and $\left[\mathrm{Zn}_{2}(\mathrm{BrL2})\left(\mathrm{CH}_{3} \mathrm{COO}\right)_{2}\right]\left(\mathrm{PF}_{6}\right)$.

BDNPP. The sequence $k_{\text {cat }} p-\mathrm{CH}_{3}>p-\mathrm{Br}>p-\mathrm{NO}_{2}$ is in accord with a previous example, $\left[\mathrm{Fe}(\mathrm{III}) \mathrm{Zn}(\mathrm{II})(\mathbf{L 1})(\mathrm{OAc})_{2}\right]^{+}\left(\mathrm{H}_{2} \mathbf{L 1}=\right.$ 2--(((3-((bis(pyridin-2-ylmethyl)amino)methyl)-2-hydroxy-5-methylbenzyl)(pyridin-2-ylmethyl)amino)-methyl)phenol), where the 
same sequence of reactivity for the substrate BDNPP was observed. ${ }^{54}$ The linear relationship between $\sigma$ and $\mathrm{p} K_{\mathrm{a} 2}$, the catalytically relevant dissociation constant, for $\left[\mathrm{Fe}(\mathrm{III}) \mathrm{Zn}(\mathrm{II})(\mathbf{L 1})(\mathrm{OAc})_{2}\right]^{+}$suggested that the para-substituent influenced the acidity of the $\mathrm{Fe}(\mathrm{III})-\mathrm{OH}_{2}$ group. ${ }^{54}$ The small range of $\mathrm{p} K_{\mathrm{a}}$ values, and inherent errors, and the lower charge for di-Zn(II) complexes makes a similar analysis more problematic. What is clear is that in the complexes based on $\mathbf{L 2}$ the hydrolase activity towards BDNPP is enhanced by the introduction of an electron donating substituent. There is no clear relationship for $\left[\mathrm{Fe}(\mathrm{III}) \mathrm{Zn}(\mathrm{II})(\mathbf{L 1})(\mathrm{OAc})_{2}\right]^{+}$nor the di- $\mathrm{Zn}(\mathrm{II})$ complexes between the Hammett parameter, $\sigma$, and $K_{\mathrm{m}}$ suggesting that the effect of the substituent is primarily on the nucleophile and not on the binding of the substrate to the metal centre. For the di-Zn(II) complexes the influence of the para-substituent accounts for less than an order of magnitude change in $k_{\text {cat }}$ but this effect in combination with previous studies which showed that second coordination sphere hydrogen bonding effects can also improve the efficiency of model system $\mathrm{s}^{5,56}$ suggests that an approach combining both influences may be effective.

Interestingly, for the complex $\left[\mathrm{Zn}_{2}\right.$ (bomp) $\left.\left(\mathrm{CH}_{3} \mathrm{COO}\right)_{2}\right] \mathrm{BPh}_{4}$ (bomp $=2,6$-bis[bis(2-methoxyethyl)aminomethyl]-4-methylphenol), an aminopeptidase mimic, when the para-methyl group was replaced by $p-\mathrm{Cl}$ and $p-\mathrm{NO}_{2}$ and the aminopeptidase activity studied using the substrate L-leucine- $p$-nitroanilide, the $\mathrm{NO}_{2}$ complex was found to be the most active, the reactivity sequence being $\mathrm{NO}_{2}>\mathrm{Cl}>\mathrm{CH}_{3} .{ }^{57}$ The difference between the two mechanisms is that the hydrolase mimics suggest a terminal hydroxide whereas the aminopeptidase mimic suggests a bridging hydroxide as the nucleophile. ${ }^{54,57}$

\section{Mechanism of reaction}

Comparison of the methyl and phenyl ether complexes $\left[\mathrm{Zn}_{2}\left(\mathrm{CH}_{3} \mathbf{L} 2\right)\left(\mathrm{CH}_{3} \mathrm{COO}\right)_{2}\right]\left(\mathrm{PF}_{6}\right), \quad\left[\mathrm{Zn}_{2}\left(\mathrm{CH}_{3} \mathbf{L} \mathbf{2}\right)\left(\mathrm{CH}_{3} \mathrm{COO}\right)_{2}\right]\left(\mathrm{PF}_{6}\right)$ and the analogue $\left[\mathrm{Zn}_{2}\left(\mathrm{CH}_{3} \mathrm{HL1}\right)\left(\mathrm{CH}_{3} \mathrm{COO}\right)\left(\mathrm{H}_{2} \mathrm{O}\right)\right]\left(\mathrm{PF}_{6}\right)$ towards the activated substrate BDNPP offers the opportunity to investigate the relative activities of potential nucleophilic zinc(II)-bound pendant alcohol ( $\mathrm{Zn}-\mathrm{OR})$ or hydroxide $(\mathrm{Zn}-\mathrm{OH})$ groups. Previous potentiometric studies have shown that $\left[\mathrm{Zn}_{2}\left(\mathrm{CH}_{3} \mathrm{HL1}\right)\left(\mathrm{CH}_{3} \mathrm{COO}\right)\left(\mathrm{H}_{2} \mathrm{O}\right)\right]\left(\mathrm{PF}_{6}\right)$ displays two $\mathrm{p} K_{\mathrm{a}} \mathrm{s}$ at 7.2 and 8.1.24 Based on a comparison to other $\mathrm{Zn}$ (II) complexes $^{21-25,27,58,59}$ and theoretical studies, ${ }^{28} \mathrm{p} K_{\mathrm{a}}=7.2$ was assigned to the alkoxide group and $\mathrm{p} K_{\mathrm{a}}=8.1$ to the hydroxide. For monomeric $\mathrm{Zn}$ (II) systems it was shown that the metal-bound alcohol nucleophile is more reactive than the metal-bound hydroxide. ${ }^{26-28}$ Thus, the mechanism proposed for $\left[\mathrm{Zn}_{2}\left(\mathrm{CH}_{3} \mathrm{HL1}\right)\right]^{2+}$ involves a nucleophilic attack by the zincbound deprotonated alcohol group $\left(\mathrm{p} K_{\mathrm{a}}=7.2\right)$, which leads to the formation of a "transition complex" ${ }^{24}$ Following breakage of the P-O bond of the substrate BPNPP and release of a nitrophenolate it remains unclear how the active site is regenerated. The nucleophilic attack by the alkoxide is expected to result in a complex with a covalently bound PNPP species, similar to that suggested for other copper(II) and zinc(II) complexes. ${ }^{22,25,60,61}$ It has been proposed that PNPP is replaced by acetate groups to reform the catalytic site, ${ }^{24}$ but the precise details for this process are currently unknown.
In contrast to $\left[\mathrm{Zn}_{2}\left(\mathrm{CH}_{3} \mathrm{HL1}\right)\right]^{2+}, \quad\left[\mathrm{Zn}_{2}\left(\mathrm{CH}_{3} \mathbf{L 2}\right)\left(\mathrm{CH}_{3}\right.\right.$ $\left.\mathrm{COO})_{2}\right]\left(\mathrm{PF}_{6}\right)$ and $\left[\mathrm{Zn}_{2}\left(\mathrm{CH}_{3} \mathbf{L 3}\right)\left(\mathrm{CH}_{3} \mathrm{COO}\right)_{2}\right]\left(\mathrm{PF}_{6}\right)$ have only one kinetically relevant $\mathrm{p} K_{\mathrm{a}}$ (6.76 and 7.72, respectively), and the absence of the metal-bound alcohol allow the assignment of this $\mathrm{p} K_{\mathrm{a}}$ to a zinc(II)-bound water molecule. Thus, this terminal hydroxide is the likely nucleophile in the reaction catalyzed by these two complexes. In order to explore the mechanism employed by these three systems further the incorporation of ${ }^{18} \mathrm{O}$ into the reaction product was monitored by NMR. Previous studies have shown that incorporation of ${ }^{18} \mathrm{O}\left(\right.$ as $\left.\mathrm{Zn}-{ }^{18} \mathrm{OH}\right)$ into a phosphate ester hydrolysis product results in a $\sim 0.02 \mathrm{ppm}$ shift in the ${ }^{31} \mathrm{P}$ NMR signal as a result of ${ }^{18} \mathrm{O}$ incorporation into the product. ${ }^{62-64} 50 \%$ incorporation of the ${ }^{18} \mathrm{O}$ would be expected to result in a splitting of the original ${ }^{31} \mathrm{P}$ resonance attributed to the hydrolyzed substrate. Therefore a solvent mixture of $\mathrm{H}_{2} \mathrm{O}^{16} / \mathrm{H}_{2} \mathrm{O}^{18}$ $(50 \mathrm{vol} \%)$ in acetonitrile was employed in the reaction of $\left[\mathrm{Zn}_{2}\left(\mathrm{CH}_{3} \mathbf{L} 2\right)\left(\mathrm{CH}_{3} \mathrm{COO}\right)_{2}\right]\left(\mathrm{PF}_{6}\right), \quad\left[\mathrm{Zn}_{2}\left(\mathrm{NO}_{2} \mathbf{L} 2\right)\left(\mathrm{CH}_{3} \mathrm{COO}\right)_{2}\right]\left(\mathrm{PF}_{6}\right)$ and $\left[\mathrm{Zn}_{2}\left(\mathrm{CH}_{3} \mathrm{HL1}\right)\left(\mathrm{CH}_{3} \mathrm{COO}\right)\left(\mathrm{H}_{2} \mathrm{O}\right)\right]\left(\mathrm{PF}_{6}\right)$ with BDNPP. In the absence of the label, no splitting in the ${ }^{31} \mathrm{P}$ NMR signal of the coordinated product of the reaction was observed in any sample. For $\left[\mathrm{Zn}_{2}\left(\mathrm{CH}_{3} \mathbf{L 2}\right)\left(\mathrm{CH}_{3} \mathrm{COO}\right)_{2}\right]\left(\mathrm{PF}_{6}\right)$ and $\left[\mathrm{Zn}_{2}\left(\mathrm{NO}_{2} \mathbf{L 2}\right)\left(\mathrm{CH}_{3} \mathrm{COO}\right)_{2}\right]\left(\mathrm{PF}_{6}\right)$ in the presence of the $\mathrm{H}_{2} \mathrm{O}^{16} / \mathrm{H}_{2} \mathrm{O}^{18}$ mixture the ${ }^{31} \mathrm{P}$ NMR of the products showed a $\sim 0.02 \mathrm{ppm}$ splitting in resonances arising at -2.70 and -3.28 ppm, respectively. For $\left[\mathrm{Zn}_{2}\left(\mathrm{CH}_{3} \mathrm{HL1}\right)\left(\mathrm{CH}_{3} \mathrm{COO}\right)\left(\mathrm{H}_{2} \mathrm{O}\right)\right]\left(\mathrm{PF}_{6}\right)$ the ${ }^{31} \mathrm{P}$ NMR spectrum again showed a $\sim 0.02 \mathrm{ppm}$ splitting, the resonance arising at $-10.9 \mathrm{ppm}$. The incorporation of the ${ }^{18} \mathrm{O}$ label in the product of the reaction suggests that for all three complexes the $\mathrm{Zn}-\mathrm{OH}$ moiety has a significant nucleophilic role, ${ }^{64}$ but the different chemical shifts observed for $\mathbf{L 1}$ and the two $\mathbf{L 2}$ systems suggest that the substrate in $\left[\mathrm{Zn}_{2}\left(\mathrm{CH}_{3} \mathrm{HL1}\right)\right]^{2+}$ may be coordinated differently from the other systems.

The NMR results, however, do not entirely rule out a role for the alkoxide in reactions of $\left[\mathrm{Zn}_{2}\left(\mathrm{CH}_{3} \mathrm{HL1}\right)\left(\mathrm{CH}_{3} \mathrm{COO}\right)\left(\mathrm{H}_{2} \mathrm{O}\right)\right]\left(\mathrm{PF}_{6}\right)$. Pathways involving both $\mathrm{Zn}-\mathrm{OH}$ and $\mathrm{Zn}-\mathrm{OR}$ nucleophiles have been suggested previously. $22,60,61$ Thus, the di-zinc(II) complex of 4-(2-hydroxyethyl)-1,4,7,16,19,22-hexaaza-10,13,25,28tetraoxacyclotriacontane, with both $\mathrm{Zn}-\mathrm{OR}$ and $\mathrm{Zn}-\mathrm{OH}$ moieties present as potential nucleophiles, has been employed to investigate the hydrolysis of carboxyester 4-nitrophenyl acetate (NA) and the phosphate ester BPNPP. ${ }^{22}$ For NA hydrolysis it was suggested that the $\mathrm{Zn}$-alkoxide acted as a nucleophile to give an acetyl derivative which was subsequently hydrolyzed to acetate by a $\mathrm{Zn}-\mathrm{OH}$ nucleophile, with regeneration of the catalyst. ${ }^{22}$ For BPNPP hydrolysis nucleophilic attack of the alkoxide led to a pendant alcohol phosphorylated intermediate which, after attack of the $\mathrm{Zn}-\mathrm{OH}$ nucleophile, led to a phosphomonoester complex. ${ }^{22}$ It may be that for $\left[\mathrm{Zn}_{2}\left(\mathrm{CH}_{3} \mathrm{HL1}\right)\left(\mathrm{CH}_{3} \mathrm{COO}\right)\left(\mathrm{H}_{2} \mathrm{O}\right)\right]\left(\mathrm{PF}_{6}\right)$ when both $\mathrm{Zn}$ (II)-alkoxide or $\mathrm{Zn}$ (II)-OH are present, similar sequential involvement of the nucleophiles occurs offering a pathway for incorporation of the ${ }^{18} \mathrm{O}$ label ${ }^{22}$ and consequently a pathway for regeneration of the active form (Fig. 6). ${ }^{19,22}$ In contrast, the mechanism employed by the $\mathbf{L} \mathbf{2}$ and $\mathbf{L} \mathbf{3}$ systems is similar to that proposed for related binuclear complexes such as the mimics of the enzyme purple acid phosphatase (PAP). ${ }^{43,45,46,65,66}$ A nucleophilic attack by the terminally-bound hydroxide initiates hydrolysis and exchange of the metal-coordinated PNPP product by water molecules regenerates the active site for the next catalytic cycle. 

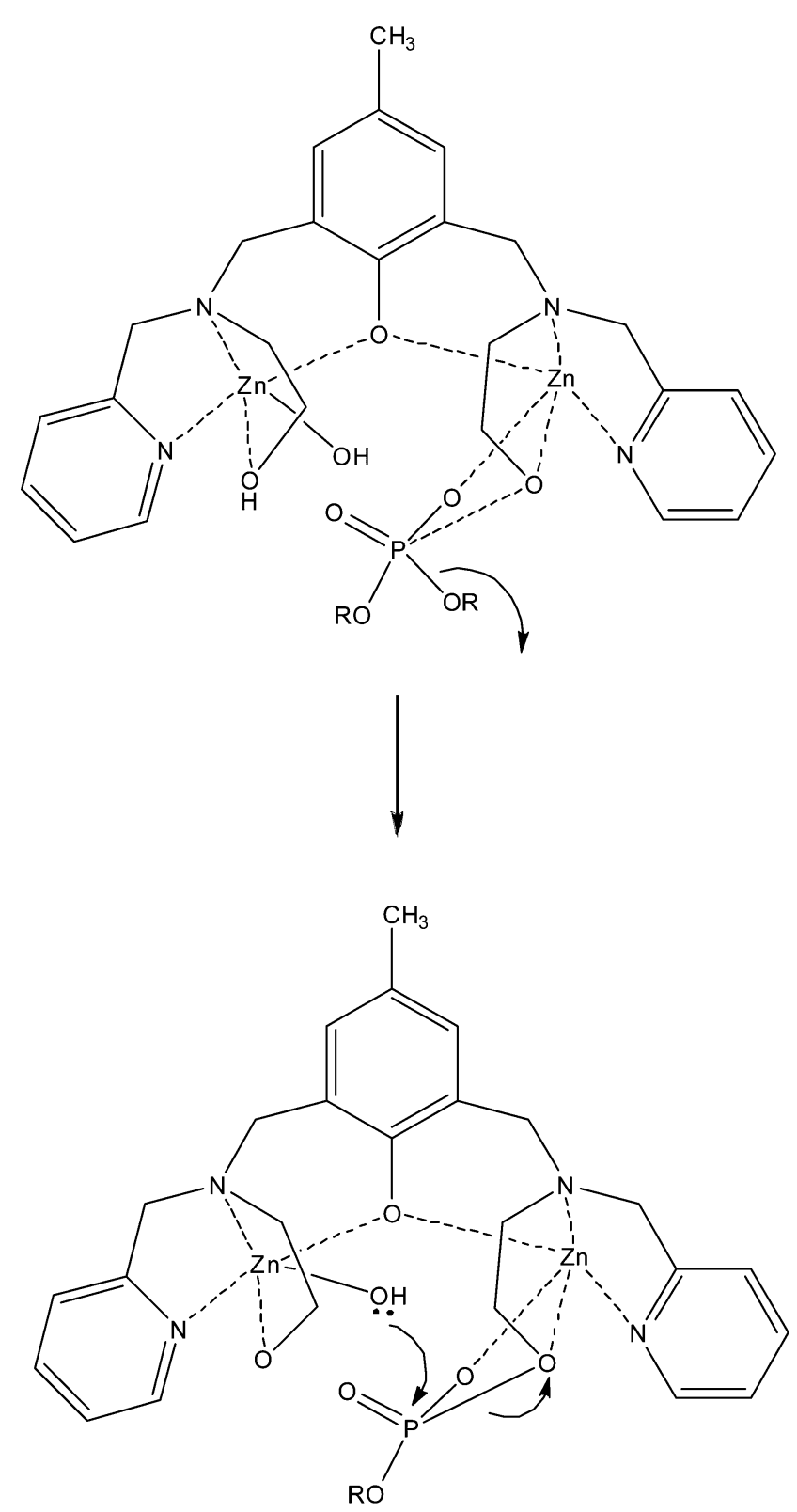

Fig. 6 Key steps in the mechanism, similar to that proposed for the alkoxide assisted hydrolysis mechanisms for the dinuclear zinc alkaline phosphatase enzyme where both the nucleophilic RO-Zn(II) and $\mathrm{OH}-\mathrm{Zn}$ (II) are involved in the hydrolytic process. ${ }^{19}$

\section{Conclusion}

The di-zinc(II) complexes reported here possess properties analogous to binuclear metallohydrolases. ${ }^{3,5,65}$ The results obtained for the hydrolysis of the activated substrate BDNPP suggest that complexes with $\mathrm{CH}_{3} \mathbf{L 2}^{-}$and $\mathrm{CH}_{3} \mathbf{L 3}^{-}$were more effective than with $\mathrm{CH}_{3} \mathrm{HL1}$, but electron-withdrawing para-substituents lower the rate of hydrolysis of BDNPP. Previous studies with the complex $\left[\mathrm{Zn}_{2}\left(\mathrm{CH}_{3} \mathrm{HL1}\right)\left(\mathrm{CH}_{3} \mathrm{COO}\right)\left(\mathrm{H}_{2} \mathrm{O}\right)\right]\left(\mathrm{PF}_{6}\right)^{24}$ and related complexes with a coordinated alcohol moiety ${ }^{22,60,61}$ suggested that the corresponding alkoxide was the nucleophilic agent in the reaction of these model systems with phosphate esters. The present study does not rule out this possibility but it indicates, based on an analysis of the incorporation of ${ }^{18} \mathrm{O}$ into the hydrolysis product, that the three systems investigated here may employ a similar mechanistic strategy with a metal-bound hydroxide as nucleophile. The previously proposed model for the mechanism of $\left[\mathrm{Zn}_{2}\left(\mathrm{CH}_{3} \mathrm{HL1}\right)\right]^{2+}$ may still be applicable but would likely require the dual action of both the alkoxide and hydroxide nucleophiles, similar to the reaction scheme proposed for alkaline phosphatases. ${ }^{19}$ In contrast, the remaining complexes in this study are good functional models for enzyme systems that do not have covalent reaction intermediates, such as PAPs or OP-degrading hydrolases. ${ }^{2,3,46}$

\section{Experimental}

\section{Materials and methods}

Nuclear Magnetic Resonance (NMR) spectra were measured with Bruker AV300, AV400 and AV500 instruments. The spectra were recorded in $\mathrm{CDCl}_{3}, \mathrm{CD}_{3} \mathrm{OD}, \mathrm{CD}_{3} \mathrm{COCD}_{3}, \mathrm{CD}_{3} \mathrm{CN}$ or $\left(\mathrm{CD}_{3}\right)_{2} \mathrm{SO}$. Chemical shifts were determined in $\mathrm{ppm}$, relative to known residual solvent peak references. Coupling constants are given in $\mathrm{Hz}$. Two-dimensional correlation spectroscopy (COSY), heterobinuclear single quantum correlation (HSQC) and heterobinuclear multiple bond connectivity (HMBC) experiments were used to assign each signal in the spectra of the final ligands. Low resolution mass spectral data were collected with a Bruker Esquire high capacity ion trap electrospray mass spectrometer (HCT ESI-MS), in methanol $(\mathrm{MeOH})$ or acetonitrile $(\mathrm{MeCN})$ or 50:50 MeCN : water, with a Bruker ES source. High resolution mass spectra were obtained using a Bruker microTOFQ ESI-MS in $\mathrm{MeOH}$. The predicted isotopic splitting patterns of peaks were calculated using the program Molecular Weight Calculator. ${ }^{67}$ Elemental analyses were performed using the microanalysis facilities at The University of Queensland.

\section{Syntheses of ligands and complexes}

2,6-Bis(chloromethyl)-4-methylphenol, ${ }^{68} \quad 2$-(pyridyl-2-ylmethylamino)ethanol, ${ }^{69}$ 2,6-bis(bromomethyl)-4-nitrophenol, ${ }^{70}$ 2,2'-(2hydroxy-5-methyl-1,3-phenylene)bis(methylene)bis((pyridin-2-ylmethyl)azanediyl)diethanol $\left(\mathrm{CH}_{3} \mathrm{H}_{3} \mathbf{L 1}\right),{ }^{24}$ and $\left[\mathrm{Zn}_{2}\left(\mathrm{CH}_{3} \mathrm{HL1}\right)-\right.$ $\left.\left(\mathrm{CH}_{3} \mathrm{COO}\right)\left(\mathrm{H}_{2} \mathrm{O}\right)\right]\left(\mathrm{PF}_{6}\right)$ were prepared as described previously. ${ }^{24}$

Synthesis of 2-methoxy- $\boldsymbol{N}$-(pyridin-2-ylmethyl)ethanamine. Pyridine 2-carboxaldehyde $(2.25 \mathrm{~g}, 0.02 \mathrm{~mol})$ in methanol $(5 \mathrm{~mL})$ was added dropwise to 2-methoxyethanolamine (1.58 g, 0.02 $\mathrm{mol})$ in methanol $(10 \mathrm{~mL})$ at $0{ }^{\circ} \mathrm{C}$. The solution was brought to room temperature and stirred overnight. Sodium borohydride $(0.83 \mathrm{~g}, 0.02 \mathrm{~mol})$ was added in small portions at $0{ }^{\circ} \mathrm{C}$ and the solution was subsequently stirred for a further $2 \mathrm{~h}$. Water $(30 \mathrm{~mL})$ was added and the reaction mixture was concentrated to $30 \mathrm{~mL}$ in vacuo. The solution was extracted with dichloromethane $(3 \times$ $20 \mathrm{~mL}$ ) and the combined organic extracts were washed three times with brine, the solution was dried over $\mathrm{Na}_{2} \mathrm{SO}_{4}$ and the solvent was removed under vacuum. The desired product was obtained as a yellow oil in $90.6 \%$ yield $(2.85 \mathrm{~g}) .{ }^{1} \mathrm{H} \mathrm{NMR}\left(\mathrm{CDCl}_{3}\right.$, $300.13 \mathrm{MHz}) ; \delta 2.26(\mathrm{~s}, 1 \mathrm{H}, \mathrm{NH}) ; 2.72\left(\mathrm{t}, 2 \mathrm{H}, \mathrm{HN}-\mathrm{CH}_{2-}, J=\right.$ $5.4 \mathrm{~Hz}) ; 3.20\left(\mathrm{~s}, 3 \mathrm{H}, \mathrm{OCH}_{3}\right) ; 3.43\left(\mathrm{t}, 2 \mathrm{H}, \mathrm{CH}_{2}-\mathrm{O}, J=5.4 \mathrm{~Hz}\right)$; 3.79 (s, 2H, HN-CH - ar); $7.02(\mathrm{dq}, 1 \mathrm{H}$, pyCH, $J=7.5,4.9 \mathrm{~Hz})$; $7.19(\mathrm{dt}, 1 \mathrm{H}$, pyCH, $J=7.7,1.0 \mathrm{~Hz}) ; 7.48(\mathrm{td}, 1 \mathrm{H}$, pyCH, $J$ $=7.6,1.8 \mathrm{~Hz}) ; 8.40(\mathrm{dq}, 1 \mathrm{H}$, pyCH$, J=4.9,1.73,0.9 \mathrm{~Hz}) \cdot{ }^{13} \mathrm{C}$ 
NMR $\left(\mathrm{CDCl}_{3}, 100.62 \mathrm{MHz}\right) ; \delta 48.6\left(\mathrm{HN}-\mathrm{CH}_{2}\right) ; 54.9\left(\mathrm{OCH}_{3}\right)$; $58.8\left(\mathrm{HN}-\mathrm{CH}_{2}-\mathrm{ar}\right) ; 71.8\left(\mathrm{CH}_{2}-\mathrm{O}\right) ; 121.7(\mathrm{CH}) ; 121.9(\mathrm{CH})$; $136.2(\mathrm{CH}) ; 149.1(\mathrm{CH}) ; 159.6(\mathrm{CH})$. ESI mass spectrometry (methanol) $\mathrm{m} / z 167.10\left[\mathrm{C}_{9} \mathrm{H}_{14} \mathrm{~N}_{2} \mathrm{OH}\right]^{+}$. FT-IR spectroscopy $(v$, $\left.\mathrm{cm}^{-1}\right) 3318.5$ (m, N-H str); 2889.1, 2830.3 (m, C-H str); 1592.2 (m, C =C str); 1434.7 (m, C-H def); 1356.5 (w, C-H sym. def); 1110.0 (s, C-O-C str); 757.1 (s, py-H).

Synthesis of 2-phenoxy- $\mathrm{N}$-(pyridin-2-ylmethyl)ethanamine. Pyridine 2-carboxaldehyde $(0.39 \mathrm{~g}, 0.004 \mathrm{~mol})$ in methanol $(2 \mathrm{~mL})$ was added dropwise to 2-phenoxyethanolamine $(0.5 \mathrm{~g}, 0.004$ mol) in methanol $(3 \mathrm{~mL})$ at $0{ }^{\circ} \mathrm{C}$. The solution was brought to room temperature and stirred overnight. Subsequently sodium borohydride $(0.2 \mathrm{~g}, 0.005 \mathrm{~mol})$ was added in small portions and the solution was stirred for a further $4 \mathrm{~h}$. Water $(6 \mathrm{~mL})$ was added and the reaction mixture was concentrated to about $6 \mathrm{~mL}$ in vacuo. The remaining solution was extracted with dichloromethane (3 $\times 10 \mathrm{~mL}$ ) and the combined organic extracts were dried over $\mathrm{Na}_{2} \mathrm{SO}_{4}$ and the solvent was removed under vacuum to yield 0.75 $\mathrm{g}$ of a yellow oil in $91.2 \%$ yield. ${ }^{1} \mathrm{H}$ NMR $\left(\mathrm{CDCl}_{3}, 500.13 \mathrm{MHz}\right)$; $\delta 2.14(\mathrm{~s}, 1 \mathrm{H}, \mathrm{N} H) ; 3.04\left(\mathrm{t}, 2 \mathrm{H}, \mathrm{HN}-\mathrm{CH}_{2}, J=5.3 \mathrm{~Hz}\right) ; 3.98$ (s, $\left.2 \mathrm{H}, \mathrm{HN}-\mathrm{CH}_{2}-\mathrm{ar}\right) ; 4.09$ (t, $\left.2 \mathrm{H}, \mathrm{CH}_{2}-\mathrm{O}, J=5.3 \mathrm{~Hz}\right) ; 6.89(\mathrm{~m}, 2 \mathrm{H}$, $\operatorname{arCH}) ; 6.91(\mathrm{~m}, 1 \mathrm{H}, \operatorname{arC} H) ; 7.13(\mathrm{~m}, 1 \mathrm{H}, \mathrm{pyC} H, J=7.3,4.9,1.0$ $\mathrm{Hz}) ; 7.24(\mathrm{~m}, 2 \mathrm{H}, \operatorname{arCH}, J=7.4 \mathrm{~Hz}) ; 7.31(\mathrm{~d}, 1 \mathrm{H}, \mathrm{pyCH}, J=7.8$ $\mathrm{Hz}) ; 7.61(\mathrm{td}, 1 \mathrm{H}, \mathrm{pyC} H, J=7.7,1.8 \mathrm{~Hz}) ; 8.54(\mathrm{dq}, 1 \mathrm{H}, \mathrm{pyC} H$, $J=4.9,1.7,0.9 \mathrm{~Hz}) .{ }^{13} \mathrm{C} \mathrm{NMR}\left(\mathrm{CDCl}_{3}, 100.62 \mathrm{MHz}\right) ; \delta 48.4$ $\left(\mathrm{HN}-\mathrm{CH}_{2}\right) ; 55.1\left(\mathrm{HN}-\mathrm{CH}_{2}-\mathrm{ar}\right) ; 67.3\left(\mathrm{CH}_{2}-\mathrm{O}\right) ; 114.5(\operatorname{ar} C \mathrm{H})$; $120.7(\operatorname{ar} C H) ; 121.9($ py $C H) ; 122.1($ py $C H) ; 129.3(\operatorname{ar} C H) ; 136.4$ (py $C \mathrm{H}) ; 124.3($ py $C H) ; 158.8(\mathrm{O}-C) ; 159.6\left(\mathrm{CH}_{2}-\right.$ pyC). ESI mass spectrometry (methanol) $\mathrm{m} / z 229.10\left[\mathrm{C}_{14} \mathrm{H}_{16} \mathrm{~N}_{2} \mathrm{OH}\right]^{+}$. FT-IR spectroscopy $\left(v, \mathrm{~cm}^{-1}\right) 3404.8$ (m, N-H str); 2923.8 (m, C-H str); 1593.9 (m, C = C str); 1510.1 (s, N-H def); 1448.1 (m, C-H def); 1331.0 (w, C-H sym. def); 1212.3 (s, C-O-C str); 777.0 (w, Ar-H); 745.5 (s, py-H); 692.0 (w, Ar-H).

Synthesis of 2,6-bis(((2-methoxyethyl)(pyridin-2-ylmethyl)amino)methyl)-4-methylphenol ( $\mathrm{CH}_{3} \mathbf{H L 2}$ ). To a solution of 2-methoxy- $N$-(pyridin-2-ylmethyl)aminoethanol $(1.50 \mathrm{~g}, 0.009$ $\mathrm{mol})$ and triethylamine $(0.91 \mathrm{~g}, 0.009 \mathrm{~mol})$ in tetrahydrofuran $(4.5 \mathrm{~mL})$ was added dropwise a solution of 2,6-bis(chloromethyl)4-methylphenol $(0.94 \mathrm{~g}, 5 \mathrm{mmol})$ in dichloromethane $(4 \mathrm{~mL})$ at 0 ${ }^{\circ} \mathrm{C}$. A white precipitate formed immediately. The reaction mixture was stirred for $48 \mathrm{~h}$ and then filtered to remove precipitated triethylamine hydrochloride. Removal of the solvents left a yellow oil $(2.17 \mathrm{~g})$ which was further purified by flash column chromatography (EtOAc/MeOH 8:2 (900 mL), EtOAc/MeOH $1: 1(400 \mathrm{~mL}), \mathrm{I}_{2}$ stain, $R_{\mathrm{f}}=0.66$ in EtOAc/MeOH $\left.8: 2\right)$. The ligand was obtained as yellow oil in $65.4 \%$ yield $(1.35 \mathrm{~g}) .{ }^{1} \mathrm{H}$ NMR $\left(\mathrm{CDCl}_{3}, 500.13 \mathrm{MHz}\right) ; \delta 2.21\left(\mathrm{~s}, 3 \mathrm{H}, \mathrm{CH}_{3}\right) ; 2.75\left(\mathrm{t}, 2 \mathrm{H}, \mathrm{N}-\mathrm{CH}_{2}, J\right.$ $=5.8 \mathrm{~Hz}) ; 3.25\left(\mathrm{~s}, 6 \mathrm{H}, \mathrm{OCH}_{3}\right) ; 3.50\left(\mathrm{t}, 4 \mathrm{H}, \mathrm{CH}_{2} \mathrm{OCH}_{3}, J=5.8 \mathrm{~Hz}\right)$; 3.77 (s, $\left.4 \mathrm{H}, \operatorname{arCH} H_{2} \mathrm{~N}\right) ; 3.84$ (s, $4 \mathrm{H}, \mathrm{NCH}_{2}$ ar); 6.92 (s, $2 \mathrm{H}, \operatorname{arCH}$ ); 7.10 (ddd, $2 \mathrm{H}$, pyC $H, J=7.4,4.9,1.1 \mathrm{~Hz}) ; 7.46(\mathrm{~d}, 2 \mathrm{H}, \operatorname{pyC} H, J=$ $7.8 \mathrm{~Hz}) ; 7.60(\mathrm{td}, 2 \mathrm{H}, \mathrm{pyC} H, J=7.6,1.8 \mathrm{~Hz}) ; 8.47(\mathrm{dq}, 2 \mathrm{H}, \mathrm{pyC} H$, $J=4.9,1.7 \mathrm{~Hz}) .{ }^{13} \mathrm{C} \mathrm{NMR}\left(\mathrm{CDCl}_{3}, 100.62 \mathrm{MHz}\right) ; \delta 20.6\left(\mathrm{CH}_{3}\right)$; $53.8\left(\mathrm{NCH}_{2}\right)$, $55.6\left(\operatorname{arCH} \mathrm{H}_{2} \mathrm{~N}\right) ; 58.7\left(\mathrm{OCH}_{3}\right) ; 60.9\left(\mathrm{NCH}_{2} \mathrm{py}\right) ; 71.0$ $\left(\mathrm{CH}_{2} \mathrm{OCH}_{3}\right) ; 123.0$ (руCH); 124.0 (руCH); $124.7(\operatorname{arC}) ; 128.2$ $(\operatorname{arCCH})_{3} ; 130.3(\operatorname{arCH}) ; 137.4($ pyCH); $149.8($ py $C H) ; 154.6$ (arC-OH); 159.8 (pyC). FT-IR spectroscopy $\left(v, \mathrm{~cm}^{-1}\right)$ 2921.8, 2875.2, $2817.0(\mathrm{~m}, \mathrm{C}-\mathrm{H}$ str); $1590.6(\mathrm{~m}, \mathrm{C}=\mathrm{C}$ str); 1434.1 (m, O-H def); 1365.0 (m, C-O-C str): 1109.1 (m, C-O str): 843.8 (m,
Ar-H); 755.9 (s, py-H). ESI mass spectrometry (methanol) $\mathrm{m} / \mathrm{z}$ $487.18\left[\mathrm{C}_{27} \mathrm{H}_{36} \mathrm{~N}_{4} \mathrm{O}_{3} \mathrm{Na}\right]^{+}, 465.22\left[\mathrm{C}_{27} \mathrm{H}_{36} \mathrm{~N}_{4} \mathrm{O}_{3} \mathrm{H}\right]^{+}$.

4-Methyl-2,6-bis(((2-phenoxyethyl)(pyridin-2-ylmethyl)amino)methyl)phenol (CH $\left.\mathbf{C H}_{3} \mathbf{H L 3}\right)$. 2,6-bis(chloromethyl)-4-methylphenol $(0.16 \mathrm{~g}, 0.55 \mathrm{mmol})$ in dichloromethane $(2 \mathrm{~mL})$ was added dropwise to a mixture of 2-phenoxy- $N$-(pyridin-2ylmethyl)ethanamine $(0.25 \mathrm{~g}, 1.09 \mathrm{mmol})$ and triethylamine $(0.30$ $\mathrm{g})$ in tetrahydrofuran $(2 \mathrm{~mL})$ at $0{ }^{\circ} \mathrm{C}$. The resulting yellow solution was stirred for $48 \mathrm{~h}$ at room temperature then filtered to remove the white precipitate of triethylamine hydrochloride and the solvent was removed under vacuum. The yellow oil was purified by flash column chromatography (EtOAc/MeOH, 9: $1, \mathrm{FeCl}_{3}$ stain, $R_{\mathrm{f}}=$ 0.75 in EtOAc/MeOH 9:1) (0.17 g, 52\%). ${ }^{1} \mathrm{H}$ NMR $\left(\mathrm{CDCl}_{3}\right.$, $500.13 \mathrm{MHz}) ; \delta 2.26\left(\mathrm{~s}, 3 \mathrm{H}, \mathrm{CH}_{3}\right) ; 3.03\left(\mathrm{t}, 4 \mathrm{H}, \mathrm{CH}_{2} \mathrm{O}, J=5.8\right.$ $\mathrm{Hz}) ; 3.88\left(\mathrm{~s}, 4 \mathrm{H}, \operatorname{arCH}_{2} \mathrm{~N}\right) ; 3.98$ (s, 4H, NCH $\left.2 \mathrm{py}\right) ; 4.10(\mathrm{t}, 4 \mathrm{H}$, $\left.\mathrm{NCH}_{2}, J=5.8 \mathrm{~Hz}\right) ; 6.85(\mathrm{~m}, 4 \mathrm{H}, \operatorname{arCH}, J=8.7,1.0 \mathrm{~Hz}) ; 6.92$ (tt, $2 \mathrm{H}, \operatorname{arCH}, J=7.4,1.0 \mathrm{~Hz}) ; 6.99$ (s, 2H, $\operatorname{arCH}) ; 7.13$ (ddd, $2 \mathrm{H}$, pyCH, $J=7.4,4.9,1.1 \mathrm{~Hz}) ; 7.24(\mathrm{~m}, 4 \mathrm{H}, \mathrm{CH}, J=7.4 \mathrm{~Hz})$; $7.49(\mathrm{~d}, 2 \mathrm{H}$, pyCH, $J=7.8 \mathrm{~Hz}) ; 7.60(\mathrm{td}, 2 \mathrm{H}$, pyCH, $J=7.6$, $1.8 \mathrm{~Hz}) ; 8.53(\mathrm{dq}, 2 \mathrm{H}$, pyCH, $J=4.8,1.7,0.8 \mathrm{~Hz}) .{ }^{13} \mathrm{C} \mathrm{NMR}$ $\left(\mathrm{CDCl}_{3}, 100.62 \mathrm{MHz}\right) ; \delta 20.5\left(\mathrm{CH}_{3}\right) ; 52.3\left(\mathrm{CH}_{2} \mathrm{O}\right), 55.2\left(\operatorname{arCH} \mathrm{H}_{2} \mathrm{~N}\right)$; $60.4\left(\mathrm{NCH}_{2}\right.$ py); $65.5\left(\mathrm{NCH}_{2}\right) ; 114.4(\operatorname{arCH}) ; 120.6(\operatorname{arCH}) ; 122.0$ (py $\mathrm{CH}) ; 123.2$ (pyCH); $123.3(\operatorname{arC}) ; 127.6\left(\mathrm{CH}_{3} C\right) ; 129.3(\operatorname{arCH})$; 136.5 (py $C H) ; 148.8$ (py $C H) ; 153.6(C O H) ; 158.6$ (py $C)$. FT-IR spectroscopy $\left(v, \mathrm{~cm}^{-1}\right)$ 2921.7, $2831.4(\mathrm{~m}, \mathrm{C}-\mathrm{H}$ str); $1596.8(\mathrm{~m}$, $\mathrm{C}=\mathrm{C} \mathrm{str}) ; 1475.4$ (m, C-H def); 1241.6 (m, C-O-Ph str); 752.2 (s, py- H); 729.9, 690.9 (s, Ar-H). ESI mass spectrometry (methanol) $m / z 611.23\left[\mathrm{C}_{37} \mathrm{H}_{40} \mathrm{~N}_{4} \mathrm{O}_{3} \mathrm{Na}\right]^{+} ; 589.25\left[\mathrm{C}_{37} \mathrm{H}_{40} \mathrm{~N}_{4} \mathrm{O}_{3} \mathrm{H}\right]^{+}$.

2,6-(((2-Methoxyethyl)(pyridin-2-ylmethyl)amino)methyl)-4nitrophenol (NO2HL2). 2-Methoxy- $N$-(pyridin-2-ylmethyl)aminoethanol $(0.51 \mathrm{~g}, 31 \mathrm{mmol})$ was dissolved with triethylamine $(0.7 \mathrm{~g})$ in $\mathrm{THF}(5 \mathrm{~mL})$ and cooled to $0{ }^{\circ} \mathrm{C}$. Upon dropwise addition of 2,6-bis(bromomethyl)-4-nitrophenol (0.5 g, $15 \mathrm{mmol})$ in dichloromethane $(7 \mathrm{~mL})$ the solution turned bright yellow and a precipitate formed immediately. The mixture was stirred for 3 days at room temperature, filtered and concentrated in vacuo. After purification by column chromatography (EtOAc/ $\mathrm{MeOH}$, $8: 1, \mathrm{FeCl}_{3}$ stain, $\left.R_{\mathrm{f}}=0.76\right)$ a yellow oil $(0.5 \mathrm{~g})$ was obtained in $68 \%$ yield. ${ }^{1} \mathrm{H} \mathrm{NMR}\left(\mathrm{CDCl}_{3}, 500.13 \mathrm{MHz}\right) ; \delta 2.80\left(\mathrm{t}, 3 \mathrm{H}, \mathrm{NCH}_{2}\right.$, $J=5.6 \mathrm{~Hz}) ; 3.29\left(\mathrm{~s}, 6 \mathrm{H}, \mathrm{OCH}_{3}\right) ; 3.52\left(\mathrm{t}, 4 \mathrm{H}, \mathrm{CH}_{2} \mathrm{OCH}_{3}, J=5.6\right.$ $\mathrm{Hz}) ; 3.85$ (s, 4H, arCH $\left.\mathrm{H}_{2} \mathrm{~N}\right) ; 3.91$ (s, 4H, $\left.\mathrm{NCH}_{2} \mathrm{py}\right) ; 7.16(\mathrm{dd}, 2 \mathrm{H}$, pyC $H, J=6.9 \mathrm{~Hz}) ; 7.42(\mathrm{~d}, 2 \mathrm{H}$, pyC $H, J=7.8 \mathrm{~Hz}) ; 7.65(\mathrm{td}, 2 \mathrm{H}$, pyC $H, J=7.8,1.7 \mathrm{~Hz}) ; 8.14(\mathrm{~s}, 2 \mathrm{H}, \operatorname{arCH}) ; 8.52$ (d, 2H, pyCH, $J=4.4 \mathrm{~Hz}) .{ }^{13} \mathrm{C} \mathrm{NMR}\left(\mathrm{CDCl}_{3}, 100.62 \mathrm{MHz}\right) ; \delta 53.2\left(\mathrm{NCH}_{2}\right)$; $54.6\left(\operatorname{arCH} \mathrm{H}_{2} \mathrm{~N}\right) ; 58.8\left(\mathrm{OCH}_{3}\right) ; 60.3\left(\mathrm{NCH}_{2} \mathrm{py}\right) ; 70.6\left(\mathrm{CH}_{2} \mathrm{OCH}_{3}\right)$; 122.2 (ру $C H), 123.0($ py $C H) ; 124.5($ py $C H) ; 125.0(\operatorname{ar} C H) ; 136.7$ (py $C \mathrm{H}) ; 139.7\left(\mathrm{CNO}_{2}\right) ; 148.9($ py $C \mathrm{H}) ; 158.5($ py $C) ; 162.5(C \mathrm{OH})$. FT-IR spectroscopy $\left(v, \mathrm{~cm}^{-1}\right) 3372.3$ (m, O-H str); 2927.1, 2877.8, 2820.8 (m, C-H str); 1591.6 (m, C=C str); 1513.7 (m, N=O asym. str); 1471.4 (m, C-H def); 1329.8 (s, N=O sym. str); 1094.5 (m, C-O str); 845.3 (w, Ar-H); 752.3 (s, py-H). ESI mass spectrometry (methanol) $\mathrm{m} / z$ 496.25 $\left[\mathrm{C}_{26} \mathrm{H}_{33} \mathrm{~N}_{5} \mathrm{O}_{5}+\mathrm{H}\right]^{+}$.

4-Bromo-2,6-bis(hydroxymethyl)phenol. 4-Bromo-2,6-bis(hydroxymethyl)phenol was prepared by a modification of a previously published procedure. ${ }^{71}$ 4-Bromophenol (17.3 g, $\left.0.1 \mathrm{~mol}\right)$ in methanol $(25 \mathrm{~mL})$, aqueous sodium hydroxide solution $(25 \%$, $50 \mathrm{~mL}$ ) and formaldehyde were combined and left at room 
temperature for 12 days. Subsequently water $(50 \mathrm{~mL})$ and glacial acetic acid $(15 \mathrm{~mL})$ were added and after $2 \mathrm{~h}$ the solution was concentrated to $50 \mathrm{~mL}$ in vacuo and then cooled on ice. The solution was decanted from the orange oil/precipitate obtained on standing and the remaining oil was dissolved in aqueous sodium hydroxide solution $(10 \%, 50 \mathrm{~mL})$. Activated charcoal was added and the suspension stirred overnight. After filtration the solution was acidified with $2 \mathrm{M} \mathrm{HCl}$ to $\mathrm{pH} 5$. The resulting yellow precipitate was collected on a sintered glass funnel, recrystallized from water, dried in air and washed with cold chloroform $(\sim 20 \mathrm{~mL})$ to yield $7 \mathrm{~g}$ of the desired product as a white powder in $23 \%$ yield. ${ }^{1} \mathrm{H} \mathrm{NMR}\left(\mathrm{CD}_{3} \mathrm{COCD}_{3}, 300.13 \mathrm{MHz}\right) ; \delta 4.73$ (s, $\left.4 \mathrm{H}, \mathrm{CH}_{2}\right) ; 7.28$ (s, $2 \mathrm{H}, \operatorname{arCH}){ }^{13} \mathrm{C}$ NMR $\left(\mathrm{CD}_{3} \mathrm{COCD}_{3}, 100.62 \mathrm{MHz}\right) ; \delta 61.4\left(\mathrm{CH}_{2}\right)$; $111.6(\operatorname{ar} C \mathrm{Br}) ; 129.5(\operatorname{arCH}) ; 130.5(\operatorname{arCCH} 2) ; 153.4(\operatorname{arCOH})$. FT-IR spectroscopy $\left(v, \mathrm{~cm}^{-1}\right) 3400.8,3300.3$ (s, O-H str); 2965.6, 2911.5, 2886.2 (w, $\mathrm{CH}_{2}$ str); 1649.0, 1610.3, 1586.9 (w, $\mathrm{C}=\mathrm{C}$ str); 1453.5 (s, $\mathrm{CH}_{2}$ def); 1331.3 (s, O-H def); 1064.7 (s, $\mathrm{C}-\mathrm{OH}$ def); 870.0 (m, Ar-H def).

\begin{abstract}
4 - Bromo - 2, 6 - bis(bromomethyl)phenol. 4-Bromo-2,6-bis(hydroxymethyl)phenol (3 g, $13 \mathrm{mmol})$ was added to hydrogen bromide in acetic acid $(30 \%, 15 \mathrm{~mL})$ and stirred for 10 min until all the starting material had dissolved. Upon addition of water the clear orange solution formed a precipitate which was collected and dried on a filter and then washed thoroughly with cold petroleum spirit. The desired product was obtained as yellow powder, $3.3 \mathrm{~g}$, in $70.5 \%$ yield. ${ }^{1} \mathrm{H}$ NMR $\left(\mathrm{CDCl}_{3}, 300.13 \mathrm{MHz}\right) ; \delta 4.49$ (s, $4 \mathrm{H}$, $\mathrm{CH}_{2}$ ); 5.66 (bs, $\left.1 \mathrm{H}, \mathrm{OH}\right) ; 7.39$ (s, $\left.2 \mathrm{H}, \operatorname{arCH}\right)^{13} \mathrm{C} \mathrm{NMR}\left(\mathrm{CDCl}_{3}\right.$, $100.62 \mathrm{MHz}) \delta 27.9\left(\mathrm{CH}_{2}\right) ; 112.7(\operatorname{arCBr}) ; 127.2\left(\operatorname{ar} C \mathrm{CH}_{2}\right) ; 133.7$ $(\operatorname{arCH}) ; 152.3$ (arCOH).FT-IR spectroscopy $\left(v, \mathrm{~cm}^{-1}\right) 3537.1$ (s, O-H str); 3050.3, 2979.8 (w, $\mathrm{CH}_{2}$ str); 1647.9, 1603.6 (w, $\mathrm{C}=\mathrm{C}$ str); 1467.1 (s, $\mathrm{CH}_{2}$ def); 868.8 (m, Ar-H def).
\end{abstract}

4-Bromo-2,6-bis(((2-methoxyethyl)(pyridin-2-ylmethyl)amino)methyl)phenol (BrHL2). To a solution of 2-methoxy- $N$-(pyridin2-ylmethyl)aminoethanol (0.925 g, $5.6 \mathrm{mmol})$ and triethylamine $(1.25 \mathrm{~g})$ in tetrahydrofuran $(10 \mathrm{~mL})$ was added dropwise a solution of 4-bromo-2,6-bis(bromomethyl)phenol ( $1 \mathrm{~g}, 2.7 \mathrm{mmol})$ in dichloromethane $(10 \mathrm{~mL})$ at $0{ }^{\circ} \mathrm{C}$. The reaction mixture was stirred for $72 \mathrm{~h}$ and then filtered to remove the precipitate of triethylamine hydrobromide. Removal of the solvent resulted in a yellow oil which was further purified by flash column chromatography $(1 \mathrm{~g}$ crude ligand, $l=30 \mathrm{~cm}, \varnothing=1.5 \mathrm{~cm}$, EtOAc (until first band is eluted) then $\mathrm{MeOH} / \mathrm{EtOAc} 1: 5, \mathrm{FeCl}_{3}$ stain, $R_{\mathrm{f}}=0.55 \mathrm{in}$ EtOAc). The ligand was obtained as a yellow oil in $63 \%$ yield $(930 \mathrm{mg}) .{ }^{1} \mathrm{H}$ NMR $\left(\mathrm{CDCl}_{3}, 300.13 \mathrm{MHz}\right) \delta 2.79(\mathrm{t}, 4 \mathrm{H}$, $\left.\mathrm{NCH}_{2} \mathrm{CH}_{2}\right) ; 3.26\left(\mathrm{~s}, 6 \mathrm{H}, \mathrm{OCH}_{3}\right) ; 3.52\left(\mathrm{t}, 4 \mathrm{H}, \mathrm{CH}_{2} \mathrm{OCH}_{3}\right) ; 3.79$ (s, $\left.4 \mathrm{H}, \mathrm{CH}_{2} \mathrm{~N}\right) ; 3.96\left(\mathrm{~s}, 4 \mathrm{H}, \mathrm{NCH}_{2} \mathrm{py}\right) ; 5.17(\mathrm{~s}, 1 \mathrm{H}, \mathrm{OH}) ; 7.08(\mathrm{~m}, 2 \mathrm{H}$, pyCH); 7.19 (s, $2 \mathrm{H}, \operatorname{arCH}) ; 7.44(\mathrm{~m}, 2 \mathrm{H}, \mathrm{pyCH}), 7.64(\mathrm{~m}, 2 \mathrm{H}$, pyCH); 8.50 (m, 2H, pyCH). ${ }^{13} \mathrm{C}$ NMR $\left(\mathrm{CDCl}_{3}, 100.62 \mathrm{MHz}\right)$; $\delta 52.8\left(\mathrm{CH}_{2}\right) ; 54.6\left(\mathrm{CH}_{2}\right) ; 58.7\left(\mathrm{CH}_{3}\right) ; 59.8\left(\mathrm{CH}_{2}\right) ; 69.9\left(\mathrm{CH}_{2}\right)$; $110.7(\operatorname{arCH}) ; 122.45($ py $C H) ; 123.6($ py $C H) ; 123.8(\operatorname{ar} C H) ;$ $131.9(\operatorname{arCH}) ; 136.8($ py $C H) ; 148.9($ py $C H) ; 156.0(\operatorname{ar} C H) ; 156.8$ (рy $\mathrm{CH}$ ). FT-IR spectroscopy $\left(v, \mathrm{~cm}^{-1}\right) 3230.6$ (m, O-H str); 2927.3, $2879.1\left(\mathrm{~m}, \mathrm{CH}_{2}\right.$ str); 1591.8, 1572.1 (m, C=C str); 1435.2 (s, $\mathrm{CH}_{2}$ def); 1111.8 (s, C-O str); 831.5, 755.7 (s, Ar-H). ESI mass spectrometry (methanol) $\mathrm{m} / \mathrm{z} 529.10,531.07\left[\mathrm{C}_{26} \mathrm{H}_{33} \mathrm{BrN}_{4} \mathrm{O}_{3}+\mathrm{H}\right]^{+}$; 551.16, $553.16\left[\mathrm{C}_{26} \mathrm{H}_{33} \mathrm{BrN}_{4} \mathrm{O}_{3}+\mathrm{Na}\right]^{+}$.
$\left[\mathbf{Z n}_{2}\left(\mathbf{C H}_{3} \mathbf{L} 2\right)\left(\mathbf{C H}_{3} \mathbf{C O O}\right)_{2}\right]\left(\mathbf{P F}_{6}\right) . \quad \mathrm{CH}_{3} \mathrm{HL2}(0.250 \mathrm{~g}, 0.5 \mathrm{mmol})$ was dissolved in $\mathrm{MeOH}(20 \mathrm{~mL})$, and a solution of zinc acetate dihydrate $(0.240 \mathrm{~g}, 0.9 \mathrm{mmol})$ in $\mathrm{MeOH}(10 \mathrm{~mL})$ was added dropwise. The resulting pale yellow solution was then heated under reflux for $0.5 \mathrm{~h}$. The solution was permitted to cool to room temperature and $\mathrm{NaPF}_{6}(0.140 \mathrm{~g}, 0.8 \mathrm{mmol})$ was added. Upon standing colourless crystals were deposited and these were collected by filtration $(0.31 \mathrm{~g}, 71 \%)$. Anal. calc. for $\mathrm{C}_{31} \mathrm{H}_{41} \mathrm{Zn}_{2} \mathrm{~N}_{4} \mathrm{O}_{7}$ $\mathrm{PF}_{6}$ : C 43.42, H 4.82, N 6.53\% Found: C 43.25, H 4.79, N 6.53\%. ESI mass spec (methanol) $m / z$ : $711.2\left[\mathrm{C}_{31} \mathrm{H}_{41} \mathrm{~N}_{4} \mathrm{O}_{7} \mathrm{Zn}_{2}\right]^{+}$. FT-IR spectroscopy $\left(v, \mathrm{~cm}^{-1}\right): 2924.0,2850.5(\mathrm{w}, \mathrm{C}-\mathrm{H}$ str), $1593.8(\mathrm{~m}$, $\mathrm{C}=\mathrm{O}$ asym str, acetate); 1476.2 ( $\mathrm{m}, \mathrm{C}=\mathrm{O}$ sym str, acetate); 1427.7 (m, C-H def); 1092.5 (w, C-O str), 830.8 (s P-F str), 555.4 (s, P-F str). ${ }^{1} \mathrm{H}$ NMR $\left(\mathrm{CD}_{3} \mathrm{CN}, 500.13 \mathrm{MHz}\right) ; \delta 1.90\left(\mathrm{~s}, 6 \mathrm{H}\right.$, acetateC $\left.H_{3}\right)$; $2.22\left(\mathrm{~s}, 3 \mathrm{H}, \mathrm{CH}_{3}\right) ; 2.52\left(\mathrm{~m}, 4 \mathrm{H}, \mathrm{NCH}_{2}, J=5.7 \mathrm{~Hz}\right) ; 2.71(\mathrm{bm}$, $\left.4 \mathrm{H}, \mathrm{CH}_{2} \mathrm{CH}_{2} \mathrm{O}\right) ; 2.98\left(\mathrm{~s}, 6 \mathrm{H}, \mathrm{OCH}_{3}\right) ; 3.63\left(\mathrm{~d}, 2 \mathrm{H}, \operatorname{arCH} H_{2} \mathrm{~N}, J\right.$ $=11.9 \mathrm{~Hz}) ; 3.85\left(\mathrm{~d}, 2 \mathrm{H}, \mathrm{NCH}_{2}\right.$ py, $\left.J=14.7 \mathrm{~Hz}\right) ; 4.39(\mathrm{~d}, 2 \mathrm{H}$, $\mathrm{NCH}_{2}$ py, $\left.J=13.8 \mathrm{~Hz}\right) ; 4.48\left(\mathrm{~d}, 2 \mathrm{H}, \operatorname{arC} H_{2} \mathrm{~N}, J=9.3 \mathrm{~Hz}\right) ; 7.03$ (s, 2H. arCH); 7.49-7.51 (m, 4H, pyCH); 7.99 (t, 2H, pyCH, $J=$ $7.4 \mathrm{~Hz}) ; 8.74$ (d, $2 \mathrm{H}, \mathrm{pyCH}, J=4.6 \mathrm{~Hz}) .{ }^{13} \mathrm{C} \mathrm{NMR}\left(\mathrm{CD}_{3} \mathrm{CN}\right.$, $100.62 \mathrm{MHz}) ; \delta 20.4\left(\mathrm{CH}_{3}\right) ; 24.6\left(\right.$ acetate $\left.\mathrm{CH}_{3}\right) ; 55.1\left(\mathrm{NCH}_{2}\right)$; $59.0\left(\mathrm{OCH}_{3}\right) ; 61.3\left(\operatorname{arCH} \mathrm{H}_{2} \mathrm{~N}\right) ; 61.6\left(\mathrm{NCH}_{2}\right.$ py); $69.7\left(\mathrm{CH}_{2} \mathrm{O}\right) ; 125.2$ (py $C \mathrm{H}) ; 125.8(\operatorname{arC}) ; 126.8\left(\mathrm{CCH}_{3}\right) ; 132.8(\operatorname{ar} C \mathrm{H}) ; 140.8($ py $C \mathrm{H})$; $148.6($ py $C \mathrm{H}) ; 155.8$ (py $C) ; 161.1(\mathrm{COH}) ; 177.7\left(\mathrm{CO}_{2}^{-}\right)$. Second set of low intensity (25\%) signals: ${ }^{1} \mathrm{H} N \mathrm{MR}\left(\mathrm{CD}_{3} \mathrm{CN}, 500.13 \mathrm{MHz}\right)$ $\mathrm{H}, \mathrm{H}-\mathrm{COSY} ; \delta 2.07$ (s, $6 \mathrm{H}) ; 3.12$ (s, $6 \mathrm{H}) ; 3.27$ (d, $2 \mathrm{H}, J=5.4 \mathrm{~Hz}$ ); $3.74(\mathrm{~m}, 4 \mathrm{H}) ; 3.74$ (s, $2 \mathrm{H}) ; 3.86(\mathrm{~d}, 2 \mathrm{H}, J=15.8 \mathrm{~Hz}) ; 4.01(\mathrm{~s}, 2 \mathrm{H})$; $6.77(\mathrm{~s}, 2 \mathrm{H}) ; 7.21(\mathrm{~d}, 2 \mathrm{H}, J=6.1 \mathrm{~Hz}) ; 7.37(\mathrm{t}, 2 \mathrm{H}, J=5.8 \mathrm{~Hz}) ; 7.81$ (t, $2 \mathrm{H}, J=7.3 \mathrm{~Hz}) ; 8.51$ (bs, 2H).

$\left[\mathrm{Zn}_{2}\left(\mathrm{CH}_{3} \mathbf{L 3}\right)\left(\mathrm{CH}_{3} \mathbf{C O O}\right)_{2}\right]\left(\mathbf{P F}_{6}\right) \cdot \mathbf{C H}_{3} \mathbf{O H}$. This complex was prepared in a similar manner to that described for $\left[\mathrm{Zn}_{2}\left(\mathrm{CH}_{3} \mathbf{L 2}\right)\left(\mathrm{CH}_{3} \mathrm{COO}\right)_{2}\right]\left(\mathrm{PF}_{6}\right) ;(0.31 \mathrm{~g}, 71 \%)$. Anal. calc. for $\mathrm{C}_{41} \mathrm{H}_{45} \mathrm{Zn}_{2} \mathrm{~N}_{4} \mathrm{O}_{7} \mathrm{PF}_{6} \mathrm{CH}_{3} \mathrm{OH}$ : C 49.77, H 4.87, N 5.53\% Found: C 49.50, H 4.60, N 5.55\%. ${ }^{1} \mathrm{H}$ NMR $\left(\mathrm{CD}_{3} \mathrm{CN}, 400.13 \mathrm{MHz}\right) ; \delta$ $1.72\left(\mathrm{~s}, 6 \mathrm{H}\right.$, acetateC $\left.\mathrm{H}_{3}\right) ; 2.24\left(\mathrm{~s}, 3 \mathrm{H}, \mathrm{CH}_{3}\right) ; 2.77(\mathrm{~m}, 3 \mathrm{H}) ; 3.04(\mathrm{~m}$, $3 \mathrm{H}) ; 3.37$ (d, $4 \mathrm{H}) ; 3.54$ (m, $3 \mathrm{H}) ; 3.65(\mathrm{~d}, 2 \mathrm{H}, J=12.3 \mathrm{~Hz}) ; 3.77$ (d, $2 \mathrm{H}, J=11.8 \mathrm{~Hz}) ; 3.94(\mathrm{~m}, 5 \mathrm{H}) ; 4.18(\mathrm{~m}, 5 \mathrm{H}) ; 7.21(\mathrm{~m}, 4 \mathrm{H}, \operatorname{arCH})$; $6.94(\mathrm{~m}, 2 \mathrm{H}, \operatorname{arC} H) ; 6.62(\mathrm{~d}, 4 \mathrm{H}, J=8.1 \mathrm{~Hz}, \operatorname{arC} H) ; 7.41-7.50$ $(\mathrm{m}, 4 \mathrm{H}$, pyC $H) ; 7.97(\mathrm{td}, 2 \mathrm{H}, J=7.7,1.4$, pyC $H) ; 8.71(\mathrm{~d}, 2 \mathrm{H}, J=$ 5.1, pyC $H$ ). Second set of low intensity aromatic proton signals: $7.21(\mathrm{~m}, 4 \mathrm{H}) ; 6.94(\mathrm{~m}, 2 \mathrm{H}) ; 6.73(\mathrm{~d}, 4 \mathrm{H}, J=8.6 \mathrm{~Hz}) ; 7.41-7.50$ $(\mathrm{m}, 4 \mathrm{H}) ; 7.93(\mathrm{td}, 2 \mathrm{H}, J=7.7,1.6 \mathrm{~Hz}) ; 8.75(\mathrm{~d}, 2 \mathrm{H}, J=5.3 \mathrm{~Hz})$. ESI mass spectrometry (methanol) $\mathrm{m} / \mathrm{z}: 855.7\left[\mathrm{C}_{41} \mathrm{H}_{47} \mathrm{~N}_{4} \mathrm{O}_{8} \mathrm{Zn}_{2}\right]^{+}$; $825.7\left[\mathrm{C}_{40} \mathrm{H}_{47} \mathrm{~N}_{4} \mathrm{O}_{7} \mathrm{Zn}_{2}\right]^{+}$. FT-IR spectroscopy $\left(v, \mathrm{~cm}^{-1}\right): 2927.4$ (w, $\mathrm{C}-\mathrm{H}$ str), 1593.9 (m, $\mathrm{C}=\mathrm{O}$ asym str, acetate); $1482.6(\mathrm{~m}, \mathrm{C}=\mathrm{O}$ sym str, acetate); 1433.7 (m, C-H def); 1224.6 (w, C-O str), 832.5 (s P-F str), 760.3 (s, Ph-H); 694.1 (s, Ph-H); 555.4 (s, P-F str).

$\left[\mathbf{Z n}_{2}\left(\mathbf{N O}_{2} \mathbf{L} 2\right)\left(\mathrm{CH}_{3} \mathbf{C O O}\right)_{2}\right]\left(\mathbf{P F}_{6}\right)$. This complex was prepared in a similar manner to that described for $\left[\mathrm{Zn}_{2}\left(\mathrm{CH}_{3} \mathbf{L 2}\right)\left(\mathrm{CH}_{3} \mathrm{COO}\right)_{2}\right]\left(\mathrm{PF}_{6}\right) ; \quad(0.31 \mathrm{~g}, \quad 71 \%)$. Anal. calc. for $\mathrm{C}_{30} \mathrm{H}_{38} \mathrm{Zn}_{2} \mathrm{~N}_{5} \mathrm{O}_{9} \mathrm{PF}_{6} \cdot \mathrm{CH}_{3} \mathrm{OH}$ : C $40.45, \mathrm{H} 4.60, \mathrm{~N} 7.61 \%$ Found: $\mathrm{C}$ 39.36, H 4.27, N 7.67\%. ESI mass spectrometry (methanol) $\mathrm{m} / z$ : $744.0\left[\mathrm{C}_{30} \mathrm{H}_{38} \mathrm{~N}_{5} \mathrm{O}_{9} \mathrm{Zn}_{2}\right]^{+}$. FT-IR spectroscopy $\left(v, \mathrm{~cm}^{-1}\right) 2931.1$ (w, C-H str); 1596.3 (m, C=O asym str, acetate); 1505.9 (w, $\mathrm{NO}_{2}$ asym str); 1426.3 ( $\mathrm{m}, \mathrm{C}=\mathrm{O}$ sym str, acetate); 1320.4 (m, $\mathrm{NO}_{2}$ sym str); 1091.8 (m, C-O str); 832.8 (s P-F str); 755.2 (m, py C-H def); 659.3 (w, Ar-H def); 556.1 (s, P-F). ${ }^{1} \mathrm{H}$ NMR $\left(\mathrm{CD}_{3} \mathrm{CN}, 500.13 \mathrm{MHz}\right) ; \delta 1.91\left(\mathrm{~s}, 6 \mathrm{H}\right.$, acetateC $\left.H_{3}\right) ; 2.57$ 
(m, 4H, NCH $H_{2}$ ); 2.74 (bm, 4H, $\mathrm{CH}_{2} \mathrm{CH}_{2} \mathrm{O}$ ); 2.99 (s, 6H, OCH $\mathrm{OH}_{3}$; $3.82\left(\mathrm{~d}, 2 \mathrm{H}, \operatorname{arCH} H_{2} \mathrm{~N}, J=12.3 \mathrm{~Hz}\right) ; 3.90\left(\mathrm{~d}, 2 \mathrm{H}, \mathrm{NCH}_{2}\right.$ py, $J=14.8$ $\mathrm{Hz}) ; 4.42\left(\mathrm{~d}, 2 \mathrm{H}, \mathrm{NCH}_{2}\right.$ py, $\left.J=15.1 \mathrm{~Hz}\right) ; 4.48\left(\mathrm{~d}, 2 \mathrm{H}, \operatorname{arCH}_{2} \mathrm{~N}\right.$, $J=12.7 \mathrm{~Hz}) ; 7.52(\mathrm{~m}, 4 \mathrm{H}$, pyCH$) ; 8.01(\mathrm{t}, 2 \mathrm{H}$, pyC $H, J=6.9$ $\mathrm{Hz}) ; 8.2$ (s, 2H. $\operatorname{arCH}) ; 8.72(\mathrm{~m}, 2 \mathrm{H}$, pyC $H)$.

$\left[\mathbf{Z n}_{2}(\mathbf{B r L 2})\left(\mathbf{C H}_{3} \mathbf{C O O}\right)_{2}\right]\left(\mathbf{P F}_{6}\right)$. BrHL2 $(100 \mathrm{mg})$ was dissolved in methanol $(8 \mathrm{~mL})$ with zinc acetate dihydrate $(82 \mathrm{mg})$. The mixture was heated under reflux for $30 \mathrm{~min}$, permitted to cool to room temperature and dry sodium hexafluorophosphate $(95 \mathrm{mg})$ was added. After filtration the solution was left to stand at room temperature. Colourless crystals, suitable for Xray crystallography, emerged after $2 \mathrm{~h}(62 \mathrm{mg})$. Anal calc. for $\mathrm{C}_{30} \mathrm{H}_{38} \mathrm{BrN}_{4} \mathrm{O}_{7} \mathrm{Zn}_{2} \mathrm{PF}_{6}$ C: $39.07, \mathrm{H}: 4.15$, N: $6.07 \%$ Found: $\mathrm{C}$ $39.33, \mathrm{H} 4.13$, N $6.14 \%$ ESI mass spectrometry (methanol) $m / z: 749.0\left[\mathrm{C}_{29} \mathrm{H}_{38} \mathrm{BrN}_{4} \mathrm{O}_{6} \mathrm{Zn}_{2}\right]^{+}, 707.3\left[\mathrm{C}_{27} \mathrm{H}_{36} \mathrm{BrN}_{4} \mathrm{O}_{5} \mathrm{Zn}\right]^{+}, 593.1$ $\left[\mathrm{C}_{26} \mathrm{H}_{32} \mathrm{BrN}_{4} \mathrm{O}_{3} \mathrm{Zn}\right]^{+}$. FT-IR spectroscopy $\left(v, \mathrm{~cm}^{-1}\right) 2930.0$ (w, $\mathrm{CH}_{2}$ str); 1596.9 (s, bridging acetate antisym. str); 1424.4 (s, bridging acetate sym. str); 829.4 (s, P-F str); 760.0, 657.6 (m, Ar-H def); 555.1 (m, P-F). ${ }^{1} \mathrm{H}$ NMR $\left(\mathrm{CD}_{3} \mathrm{CN}, 500.13 \mathrm{MHz}\right) ; \delta 1.99$ (s, $6 \mathrm{H}$, acetateC $\left.\mathrm{H}_{3}\right) ; 2.54\left(\mathrm{~m}, 4 \mathrm{H}, \mathrm{NCH}_{2}\right) ; 2.72\left(\mathrm{bm}, 4 \mathrm{H}, \mathrm{CH}_{2} \mathrm{CH}_{2} \mathrm{O}\right) ; 2.99$ $\left(\mathrm{s}, 6 \mathrm{H}, \mathrm{OCH}_{3}\right) ; 3.64\left(\mathrm{~d}, 2 \mathrm{H}, \operatorname{arCH} H_{2} \mathrm{~N}, J=12.1 \mathrm{~Hz}\right) ; 3.84(\mathrm{~d}, 2 \mathrm{H}$, $\mathrm{NCH}_{2}$ py, $\left.J=14.7 \mathrm{~Hz}\right) ; 4.38$ (d, $2 \mathrm{H}, \mathrm{NCH}_{2}$ py, $\left.J=14.4 \mathrm{~Hz}\right) ; 4.44$ (d, $\left.2 \mathrm{H}, \operatorname{arCH} H_{2} \mathrm{~N}, J=11.3 \mathrm{~Hz}\right) ; 7.38(\mathrm{~s}, 2 \mathrm{H} . \operatorname{arCH}) ; 7.48-7.50(\mathrm{~m}$, $4 \mathrm{H}$, pyC $H, J=5.4 \mathrm{~Hz}) ; 7.99$ (t, 2H, pyC $H, J=7.1 \mathrm{~Hz}) ; 8.72(\mathrm{~m}$, $2 \mathrm{H}, \mathrm{pyC} H)$.

$\left[\mathrm{Zn}_{4}(\mathbf{B r L 2})_{2}\left(\mathrm{PO}_{3} \mathbf{F}\right)_{2}\left(\mathrm{H}_{2} \mathbf{O}\right)_{2}\right]\left(\mathbf{P F}_{6}\right)_{2}$. This complex was prepared in a similar manner to $\left[\mathrm{Zn}_{2}(\mathrm{BrL2})(\mathrm{OAc})_{2}\right]\left(\mathrm{PF}_{6}\right)$ complex but the sodium hexafluorophosphate employed for the crystallization was wet. Colourless crystals, suitable for X-ray crystallography, were obtained upon standing $(40 \mathrm{mg})$. Anal calc. for $\mathrm{C}_{52} \mathrm{H}_{68} \mathrm{Br}_{2} \mathrm{~N}_{8} \mathrm{O}_{14} \mathrm{Zn}_{4} \mathrm{P}_{4} \mathrm{~F}_{14}:$ C: 33.94, H: 3.72, N: $6.09 \%$ Found: C 33.35, H 3.61, N 5.99\%. ESI mass spectrometry (methanol) $m / z: 754.9\left[\mathrm{C}_{26} \mathrm{H}_{32} \mathrm{BrN}_{4} \mathrm{O}_{3} \mathrm{Zn}_{2} \mathrm{PFO}_{3}\right]^{+}, 593.1\left[\mathrm{C}_{26} \mathrm{H}_{32} \mathrm{BrN}_{4} \mathrm{O}_{3} \mathrm{Zn}\right]^{+}$. FT-IR spectroscopy $\left(v, \mathrm{~cm}^{-1}\right)$ 2854.3, 2928.9, $2892.97\left(\mathrm{w}, \mathrm{CH}_{2}\right.$ str); 1460.1, 1445.2 (m, $\mathrm{CH}_{2}$ def); 1182.6 (m, $\mathrm{P}=\mathrm{O}$, str); 1121.0 (s, C-O-C str); 830.7 (s, P-F str); 774.4 (m, Py-H def); 555.1 $(\mathrm{m}, \mathrm{P}-\mathrm{F})$.

\section{X-ray crystallography}

X-ray diffraction data for crystals of $\left[\mathrm{Zn}_{2}\left(\mathrm{CH}_{3} \mathbf{L 2}\right)\left(\mathrm{CH}_{3} \mathrm{COO}\right)_{2}\right]$ $\left(\mathrm{PF}_{6}\right), \quad\left[\mathrm{Zn}_{2}\left(\mathrm{CH}_{3} \mathbf{L} 3\right)\left(\mathrm{CH}_{3} \mathrm{COO}\right)_{2}\right]\left(\mathrm{PF}_{6}\right) \cdot \mathrm{CH}_{3} \mathrm{OH}, \quad\left[\mathrm{Zn}_{2}\left(\mathrm{NO}_{2} \mathbf{L 2}\right)-\right.$ $\left.\left(\mathrm{CH}_{3} \mathrm{COO}\right)_{2}\right]\left(\mathrm{PF}_{6}\right),\left[\mathrm{Zn}_{2}(\mathrm{BrL2})(\mathrm{OAc})_{2}\right]\left(\mathrm{PF}_{6}\right)$ and $\left[\mathrm{Zn}_{4}\left(\mathrm{CH}_{3} \mathbf{L 2}\right)_{2}\right.$ $\left.\left(\mathrm{NO}_{2} \mathrm{C}_{6} \mathrm{H}_{5} \mathrm{OPO}_{3}\right)_{2}\left(\mathrm{H}_{2} \mathrm{O}\right)_{2}\right]\left(\mathrm{PF}_{6}\right)_{2}$ were collected at $293(2) \mathrm{K}$ whilst data for $\left[\mathrm{Zn}_{4}(\mathrm{BrL2})_{2}\left(\mathrm{PO}_{3} \mathrm{~F}\right)_{2}\left(\mathrm{H}_{2} \mathrm{O}\right)_{2}\right]\left(\mathrm{PF}_{6}\right)_{2}$ were collected at $150(2)$ $\mathrm{K}$. An Oxford Diffraction Gemini Ultra dual source (Mo and $\mathrm{Cu}$ ) $\mathrm{CCD}$ diffractometer with $\mathrm{Mo}\left(\lambda_{\mathrm{K} \alpha}=0.71073 \AA\right)$ or $\mathrm{Cu}\left(\lambda_{\mathrm{K} \alpha}=\right.$ $1.5418 \AA$ ) radiation was used. The structures were solved by direct methods (SIR-92) and refined (SHELXL 97) ${ }^{72}$ by full matrix least squares methods based on $F^{2}$. These programs were accessed through the WINGX 1.70 .01 crystallographic collective package. ${ }^{73}$ All non-hydrogen atoms were refined anisotropically unless they were disordered. Hydrogen atoms were fixed geometrically and were not refined. Drawings of molecules were produced with ORTEP. ${ }^{30}$ Selected crystal data and some details of refinements are given in Table 1. Selected bond distances and angles are presented in Tables 2 and 3. X-ray data were deposited with the Cambridge Crystallographic Data Centre CCDC 830841-830846. These data can be obtained free of charge from the Cambridge Crystallographic Data Centre via www.ccdc.cam.ac.uk/data_request/cif.

\section{Catalytic studies}

The phosphoesterase-like activity of each complex was determined by measuring hydrolysis of the substrate BDNPP. A Varian Cary50 Bio UV/Visible spectrophotometer with a Peltier temperature controller was used to measure changes in absorbance values in $10 \mathrm{~mm}$ quartz cuvettes. The initial rate method was employed and assays were measured such that the initial linear portion of the data was used for analysis. Product formation was determined at $25^{\circ} \mathrm{C}$ by monitoring the formation of 2,4-dinitrophenol. Throughout the $\mathrm{pH}$ range studied the extinction coefficient of this product at 400 $\mathrm{nm}$ is $12100 \mathrm{M}^{-1} \mathrm{~cm}^{-1} \cdot{ }^{45,74}$ For each assay corrections for the rate of autohydrolysis were applied. An aqueous multi-component buffer (50 $\mathrm{mM}$ in each of 2-( $N$-morpholino)ethanesulfonic acid (MES), 4-(2-hydroxyethyl)-1-piperazineethanesulfonic acid (HEPES) and 2-( $N$-cyclohexylamino)ethane sulfonic acid (CHES), with the ionic strength controlled by $250 \mathrm{mM} \mathrm{LiClO}_{4}$ ) was used. Assays were carried out in $50: 50 \mathrm{MeCN}$ : buffer, with substrate and complex initially dissolved in $\mathrm{MeCN}$. Assays conducted to investigate $\mathrm{pH}$ dependence were $40 \mu \mathrm{M}$ in complex and $5 \mathrm{mM}$ in BDNPP and showed no significant buffer effects. Substrate dependence assays were $40 \mu \mathrm{M}$ in complex and $1-11.5 \mathrm{mM}$ in BDNPP, and complex dependence assays were $20-120 \mu \mathrm{M}$ in complex and $5 \mathrm{mM}$ in BDNPP. Background assays of autohydrolysis were subtracted from the data. The change in absorbance produced by hydrolysis of BDNPP by free $\mathrm{Zn}$ (II) (from $\mathrm{Zn}\left(\mathrm{ClO}_{4}\right)_{2}$ ), in the same concentration as the complex did not differ significantly from autohydrolysis values. All data were fitted by non-linear least squares regression analysis. Mass spectral studies of the hydrolysis reaction were conducted by mixing one equivalent of $\left[\mathrm{Zn}_{2}\left(\mathrm{CH}_{3} \mathbf{L 1}\right)\left(\mathrm{CH}_{3} \mathrm{COO}\right)_{2}\right]^{+}$with twenty-five equivalents of either bis(4-nitrophenyl)phosphate (BPNPP) or 4-nitrophenylphosphate (PNPP), the latter a hydrolysis product of the former, in $1: 1$ $\mathrm{MeCN}: \mathrm{H}_{2} \mathrm{O}$, and recording the spectrum of the resulting mixture after $1 \mathrm{~h}$. BPNPP and its hydrolysis product PNPP were used as they are slower substrates and permitted more ready analysis than the substrate used for the kinetic studies (BDNPP).

\section{${ }^{18}$ O labelling Studies}

${ }^{31} \mathrm{P}$ NMR spectra were recorded with a $400 \mathrm{MHz}$ Bruker AV400 spectrometer at room temperature in the digital acquisition mode (operating frequency $161.9 \mathrm{MHz}$ ). Chemical shifts are reported in $\delta$ units relative to $85 \% \mathrm{H}_{3} \mathrm{PO}_{4}$ in $\mathrm{D}_{2} \mathrm{O}$ as external reference $\left(\delta_{\mathrm{P}}=0.00\right)$. For the ${ }^{18} \mathrm{O}$-labeled sample $\left(50 \%{ }^{18} \mathrm{O} ; 97 \%\right.$ purity $)$ (Novachem, Victoria, Australia) the solution was made up from a solution of complex $(0.01 \mathrm{mmol})$ in acetonitrile $(0.3 \mathrm{~mL}), 100$ mM HEPES buffer $\mathrm{pH} 8(0.15 \mathrm{~mL})$ and ${ }^{18} \mathrm{O}$-water $(97 \%, 0.15 \mathrm{~mL})$ (50:50 mixture of acetonitrile: buffer). To this, one equivalent BDNPP $(5.1 \mathrm{mg})$ was added and the mixture left for one week at room temperature prior to recording the ${ }^{31} \mathrm{P}$ spectra. For experiments with ${ }^{16} \mathrm{O}$-water the solution was composed of complex $(0.01 \mathrm{mmol})$ in acetonitrile $(0.3 \mathrm{~mL}), 100 \mathrm{mM}$ HEPES buffer $\mathrm{pH}$ $8(0.15 \mathrm{~mL})$ and distilled water $(0.15 \mathrm{~mL})$. To this, one equivalent BDNPP $(5.1 \mathrm{mg})$ was added and the mixture left for one week at room temperature prior to recording the ${ }^{31} \mathrm{P}$ NMR spectra. 


\section{Acknowledgements}

This work was funded by a grant from the Australian Research Council (DP0986613).

\section{References}

1 M. A. Sogorb and E. Vilanova, Toxicol. Lett., 2002, 128, 215.

2 F. M. Raushel, Curr. Opin. Microbiol., 2002, 5, 288.

3 F. Ely, J. L. Foo, C. J. Jackson, L. R. Gahan, D. Ollis and G. Schenk, Curr. Top. Biochem. Res., 2007, 9, 63.

4 D. W. Christianson and J. D. Cox, Annu. Rev. Biochem., 1999, 68, 33.

5 C. J. Jackson, P. D. Carr, J. W. Liu, S. J. Watt, J. L. Beck and D. L. Ollis, J. Mol. Biol., 2007, 367, 1047.

6 D. P. Dumas, S. R. Caldwell, J. R. Wild and F. M. Raushel, J. Biol. Chem., 1989, 264, 19659.

7 C. Jackson, P. D. Carr, H. K. Kim, J.-W. Liu, P. Herrald, N. Mitic, G. Schenk, C. A. Smith and D. L. Ollis, Biochem. J., 2006, 397, 501.

8 G. Omburo, J. Kuo, L. Mullins and F. Raushel, J. Biol. Chem., 1992, 267, 13278.

9 F. Ely, K. S. Hadler, L. R. Gahan, L. W. Guddat, D. L. Ollis and G. Schenk, Biochem. J., 2010, 432, 565.

10 C. J. Jackson, K. S. Hadler, P. D. Carr, A. J. Oakley, S. H.-C. Yip, G. Schenk and D. L. Ollis, Acta Cryst., 2008, F64, 681.

11 H. Yang, P. D. Carr, S. Y. McLoughlin, J. W. Liu, I. Horne, X. Qiu, C. M. J. Jeffries, R. J. Russell, J. G. Oakeshott and D. L. Ollis, Protein Eng., Des. Sel., 2003, 16, 135.

12 M. M. Benning, H. Shim, F. M. Raushel and H. M. Holden, Biochemistry, 2001, 40, 2712.

13 M. M. Benning, J. Kuo, F. Raushel and H. M. Holden, Biochemistry, 1995, 34, 7973.

14 C. Jackson, H. K. Kim, P. D. Carr, J. W. Liu and D. L. Ollis, Biochim. Biophys. Acta, Proteins Proteomics, 2005, 1752, 56.

15 L. R. Gahan, S. J. Smith, A. Neves and G. Schenk, Eur. J. Inorg. Chem., 2009, 2745.

16 A. J. Kirby, Angew. Chem., Int. Ed. Engl., 1996, 35, 706.

17 M. Komiyama, J. Biochem., 1995, 118, 665.

18 J. K. Bashkin, Curr. Opin. Chem. Biol., 1999, 3, 752.

19 G. Parkin, Chem. Rev., 2004, 104, 699.

20 P. J. O'Brien and D. Herschlag, Biochemistry, 2002, 41, 3207.

21 S. A. Li, D. X. Yang, D. F. Li, J. Huang and W. X. Tang, New J. Chem., 2002, 26, 1831

22 C. Bazzicalupi, A. Bencini, E. Berni, A. Bianchi, V. Fedi, V. Fusi, C. Giorgi, P. Paolettti and B. Valtancoli, Inorg. Chem., 1999, 38, 4115.

23 D. Yang, S. Li, D. Li, J. Xia, K. Yu and W. Tang, J. Chem. Soc., Dalton Trans., 2002, 4042.

24 J. W. Chen, X. Y. Wang, Y. G. Zhu, J. Lin, X. L. Yang, Y. Z. Li, Y. Lu and Z. J. Guo, Inorg. Chem., 2005, 44, 3422.

25 E. Kimura, I. Nakamura, T. Koike, M. Shionoya, Y. Kodama, T. Ikeda and M. Shiro, J. Am. Chem. Soc., 1994, 116, 4764.

26 M. Livieri, F. Mancin, U. Tonellato and J. Chin, Chem. Commun., 2004, 2862.

27 T. Koike, S. Kajitani, I. Nakamura, E. Kimura and M. Shiro, J. Am. Chem. Soc., 1995, 117, 1210.

28 J. Xia, Y. B. Shi, Y. Zhang, Q. Miao and W. X. Tang, Inorg. Chem., 2003, 42, 70.

29 P. Comba, G. N. DeIuliis, G. A. Lawrance, S. M. Luther, M. Maeder, A. L. Nolan, M. J. Robertson and P. Turner, Dalton Trans., 2003, 2188.

30 L. J. Farrugia, J. Appl. Crystallogr., 1997, 30, 565.

31 H. Sakiyama, R. Mochizuki, A. Sugawara, M. Sakamoto, Y. Nishida and M. Yamasaki, J. Chem. Soc., Dalton Trans., 1999, 997.

32 S. Petricek and A. Demsar, Polyhedron, 2010, 29, 3329.

33 A. Crochet and K. M. Fromm, Z. Anorg. Allg. Chem., 2010, 636, 1484

34 J.-W. Chen, B. Liu, X.-Q. Chen and Y.-Z. Li, Acta Cryst., 2007, C63, $\mathrm{m} 42$.

35 S. Youngme, P. Phuengphai, C. Pakawatchai, G. A. van Albada and J. Reedijk, Inorg. Chim. Acta, 2005, 358, 2125.

36 P. Shiv Halasyamani, M. J. Drewitt and D. O'Hare, Chem. Commun., $1997,867$.

37 M. Berraho, A. Vegas, M. Martinez-Ripoll and M. Rafiq, Acta Cryst., 1994, C50, 666.

38 J. Durand, L. Cot, M. R. Berraho and M. Rafiq, Acta Cryst., 1987, C43, 611.

39 R. R. Buchholz, M. E. Etienne, A. Dorgelo, R. E. Mirams, S. J. Smith, S. Y. Chow, L. R. Hanton, G. B. Jame- son, G. Schenk and L. R. Gahan, Dalton Trans., 2008, 6045.

40 J. C. Mareque Rivas, R. T. M. de Rosales and S. Parsons, Dalton Trans., 2003,4385 .

41 C. Bazzicalupi, A. Bencini, A. Bianchi, V. Fusi, C. Giorgi, P. Paoletti, B. Valtancoli and D. Zanchi, Inorg. Chem., 1997, 36, 2784.

42 B. Bauer-Siebenlist, F. Meyer, E. Farkas, D. Vidovic, J. A. Cuesta-Seijo, R. Herbst-Irmer and H. Pritzkow, Inorg. Chem., 2004, 43, 4189.

43 M. Lanznaster, A. Neves, A. J. Bortoluzzi, V. V. E. Aires, B. Szpoganicz, H. Terenzi, P. C. Severino, J. M. Fuller, S. C. Drew, L. R. Gahan, G. R. Hanson, M. J. Riley and G. Schenk, J. Biol. Inorg. Chem., 2005, 10, 319.

44 P. Karsten, A. Neves, A. J. Bortoluzzi, J. Strahle and C. MaichleMossmer, Inorg. Chem. Commun., 2002, 5, 434.

45 S. J. Smith, A. Casellato, K. S. Hadler, N. Mitic, M. J. Riley, A. J. Bortoluzzi, B. Szpoganicsz, G. Schenk, A. Neves and L. R. Gahan, J. Biol. Inorg. Chem., 2007, 12, 1207.

46 G. Schenk, R. A. Peralta, S. C. Batista, A. J. Bortoluzzi, B. Szpoganicz, A. K. Dick, P. Herrald, G. R. Hanson, R. K. Szilagyi, M. J. Riley, L. R. Gahan and A. Neves, J. Biol. Inorg. Chem., 2008, 13, 139.

47 A. K. Boudalis, R. E. Aston, S. J. Smith, R. E. Mirams, M. J. Riley, G. Schenk, A. G. Blackman, L. R. Hanton and L. R. Gahan, Dalton Trans., 2007, 5132.

48 M. Sandstrom, I. Persson and P. Persson, Acta Chem. Scand., 1990, 44, 653.

49 I. Persson, Pure Appl. Chem., 1986, 58, 1153.

50 V. Gutmann, The Donor Acceptor Approach to Molecular Interactions, Plenum, New York/London, 1978.

51 M. Munakata, S. Kitagawa and M. Miyazima, Inorg. Chem., 1985, 24, 1638.

52 I. H. Segel, Enzyme Kinetics: Behavior and analysis of rapid equilibrium and steady-state enzyme systems, Wiley-Interscience, New York, 1975.

53 Y. Simon-Manso, J. Phys. Chem. A, 2005, 109, 2006.

54 R. A. Peralta, A. J. Bortoluzzi, B. de Souza, R. Jovito, F. R. Xavier, R. A. A. Couto, A. Casellato, F. Nome, A. Dick, L. R. Gahan, G. Schenk, G. R. Hanson, F. C. S. de Paula, E. C. Pereira-Maia, S. d. P. Machado, P. C. Severino, C. Pich, T. Bortolotto, H. Terenzi, E. E. Castellano, A. Neves and M. J. Riley, Inorg. Chem., 2010, 49, 11421.

55 G. Feng, D. Natale, R. Prabaharan, J. C. Mareque-Rivas and N. H. Williams, Angew. Chem., Int. Ed., 2006, 45, 7056.

56 G. Q. Feng, J. C. Mareque-Rivas and N. H. Williams, Chem. Commun., 2006, 1845 .

57 H. Sakiyama, Y. Igarashi, Y. Nakayama, M. J. Hossain, K. Unoura and Y. Nishida, Inorg. Chim. Acta, 2003, 351, 256.

58 L. V. Penkova, A. Maciag, E. V. Rybak-Akimova, M. Haukka, V. A. Pavlenko, T. S. Iskenderov, H. Kozlowski, F. Meyer and I. O. Fritsky, Inorg. Chem., 2009, 48, 6960.

59 L. M. Berreau, Eur. J. Inorg. Chem., 2006, 273.

60 M. Young, D. Wahnon, R. Hynes and J. Chin, J. Am. Chem. Soc., 1995, 117, 9441 .

61 E. Kimura, Y. Kodama, T. Koike and M. Shiro, J. Am. Chem. Soc., 1995, 117, 8304.

62 M. Cohn and A. Hu, Proc. Natl. Acad. Sci. U. S. A., 1978, 75, 200.

63 M. C. Mitchell, R. J. Taylor and T. P. Kee, Polyhedron, 1998, 17, 433.

64 N. H. Williams, A.-M. Lebuis and J. Chin, J. Am. Chem. Soc., 1999, $121,3341$.

65 N. Mitic, S. J. Smith, A. Neves, L. W. Guddat, L. R. Gahan and G. Schenk, Chem. Rev., 2006, 106, 3338.

66 A. Neves, M. Lanznaster, A. J. Bortoluzzi, R. A. Peralta, A. Casellato, E. E. Castellano, P. Herrald, M. J. Riley and G. Schenk, J. Am. Chem. Soc., 2007, 129, 7486.

67 M. Monroe, 2004, Molecular Weight Calculator, Version 6.45, http://www.alchemistmatt.com./.

68 R. T. Paine, Y. C. Tan and X. M. Gan, Inorg. Chem., 2001, 40, 7009.

69 S. Striegler and M. Dittel, Inorg. Chem., 2005, 44, 2728.

70 J. de Mendoza, P. M. Nieto, P. Prados and C. Sanchez, Tetrahedron, 1990, 46, 671.

71 H. Sharghi, M. A. Nasseri and K. Niknam, J. Org. Chem., 2001, 66, 7287.

72 G. M. Sheldrick, SHELXL-97, Program for refinement of crystal structures, University of Göttingen, Germany, 1997.

73 L. J. Farrugia, J. Appl. Crystallogr., 1999, 32, 837.

74 S. C. Batista, A. Neves, A. J. Bortoluzzi, I. Vencato, R. A. Peralta, B. Szpoganicz, V. V. E. Aires, H. Terenzi and P. C. Severino, Inorg. Chem. Commun., 2003, 6, 1161. 